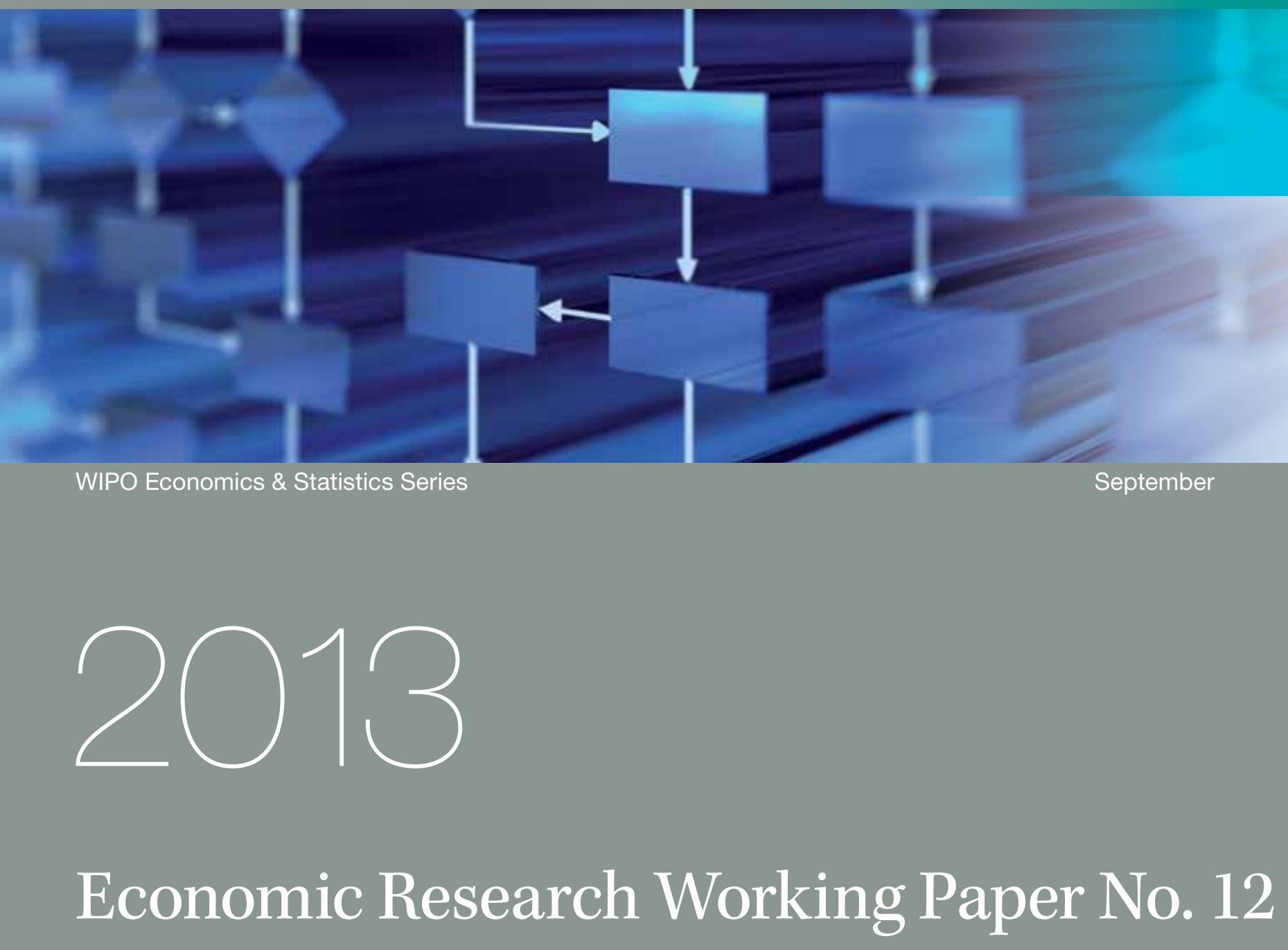

Exploring the worldwide patent surge

Carsten Fink

Mosahid Khan

Hao Zhou
WIPO

WORLD

INTELLECTUAL PROPERTY

ORGANIZATION 


\title{
EXPLORING THE WORLDWIDE PATENT SURGE
}

\author{
Carsten Fink ${ }^{*}$, Mosahid Khan ${ }^{* *}$ and Hao Zhou ${ }^{* * *}$
}

\section{September 2013}

\begin{abstract}
Worldwide patent filings are at historically unprecedented levels. In 2011, the total number of patent applications for the first time exceeded two million - double the approximately 1.05 million patents filed in 1995. Understanding what is behind this growth is important, as it may indicate faster technological progress, new innovation models and strategic shifts in how companies use the patent system. Policymakers need to understand what drives the growth in patenting worldwide, not least to evaluate how the patent system can cope with the increasing flow of applications.
\end{abstract}

A number of studies have looked at the growth in patent filings in individual countries, but have not focused on the world as a whole. This paper seeks to fill this gap by providing an analysis of global patenting trends using the most comprehensive data currently available. Among other things, it finds that subsequent patent filings - additional filings of the same invention, mostly in additional countries - contributed considerably to the growth in filings worldwide, pointing to globalization as one important driver of filing growth. However, no single factor can fully explain the marked increase in the use of the patent system.

Keywords: patents; globalization; innovation; research productivity.

\section{Disclaimer}

The views expressed in this article are those of the authors and do not necessarily reflect the views of the World Intellectual Property Organization or its member states.

\section{Acknowledgements}

The authors are grateful for valuable comments and suggestions from several WIPO colleagues as well as participants at the second Asia Pacific Innovation Conference in Singapore (May 3-4, 2011), the PCT working group meeting in Geneva (June 6-10, 2011) and the $3^{\text {rd }}$ workshop on the output of R\&D activities in Seville (June 13-14, 2011).

\footnotetext{
${ }^{*}$ World Intellectual Property Organization, Geneva, Switzerland. (email: carsten.fink@wipo.int). ${ }^{*}$ World Intellectual Property Organization, Geneva, Switzerland. (email: mosahid.khan@wipo.int).

${ }^{* \star *}$ World Intellectual Property Organization, Geneva, Switzerland. (email: hao.zhou@wipo.int).
} 


\section{INTRODUCTION}

Worldwide patent filings have reached historically unprecedented levels. Figure 1 depicts the long-term trend for selected patent offices. The numbers of applications filed at the largest patent offices were stable until the 1970s, when filings first picked up at the patent office of Japan and, later, at the office of the United States of America (US). Growth in filings at other offices, such as those of Brazil, India and especially China picked up from the mid1990 s onwards. Worldwide patent filings averaged between 800,000 and 1 million a year between 1982 and 1995, but then grew rapidly to reach 2.14 million in 2011 (WIPO, 2012). ${ }^{1}$

It is important to understand the causes behind the growth in worldwide patent filings. Firstly, increased patenting may signal accelerated technological progress, possibly increasing economic output and generating prosperity. Secondly, it may also reflect shifting innovation systems and companies reorienting their patenting strategies. A third important factor involves increased international commerce and the greater need for companies to protect their knowledge assets in international markets. A better understanding of worldwide growth in patenting is important for assessing how the international patent system functions and to what extent it serves the needs of the international community.

Against this background, a number of studies have sought to identify the causes of the socalled patent surge; however, most of these studies have focused on individual national offices paying little consideration to worldwide trends. ${ }^{2}$ For example, a number of studies have analyzed filing activity in the US and China. The reason for previous studies focusing on China and the US may partly reflect the substantial filing growth in these countries. ${ }^{3}$ To our knowledge, no study exists that has focused on the surge in worldwide patent filings. However, such a global analysis is important - not only to compare the experience of different countries, but more importantly to trace how patents transcend national borders. Our study seeks to fill this gap using the most comprehensive data currently available. ${ }^{4}$

The main aims of this paper are to provide answers to three key questions: What are the main features of the patent surge seen over the past four decades? Is it a global phenomenon or specific to certain offices or applicant origins? What are the main factors that account for the surge?

The remainder of the paper is organized as follows. Section II provides an overview of the prior literature. Section III documents the trend in worldwide patent filings, while Section IV outlines the factors that explain the filing growth. The final section provides a summary of the main findings.

\footnotetext{
${ }^{1}$ World totals are WIPO estimates covering 125 patent offices. They include both published and unpublished patent applications.

${ }^{2}$ We follow existing literature in referring to the increase in the number of patent filings as the 'patent surge'. However, there is no harmonized definition of what constitutes a 'surge' - say, in terms of average annual growth over a certain number of years.

${ }^{3}$ The growth of patent filings in the Republic of Korea also appears substantial; however, we are not aware of any study that has analyzed its causes. Japan receives a large volume of worldwide patent filings, but it has seen relatively modest growth in recent years.

${ }^{4}$ Our focus is on standard patents. We exclude utility models because there has not been a similar increase in filings for this IP right; they grew by 1.1 percent a year over the 1995-2008 period. Moreover, one patent office the State Intellectual Property Office of the People's Republic of China (SIPO) - accounted for 72 percent of applications worldwide. We also exclude provisional patent applications, except where standard applications emerge from provisional applications.
} 
Figure 1: Trend in patent filings at selected patent offices
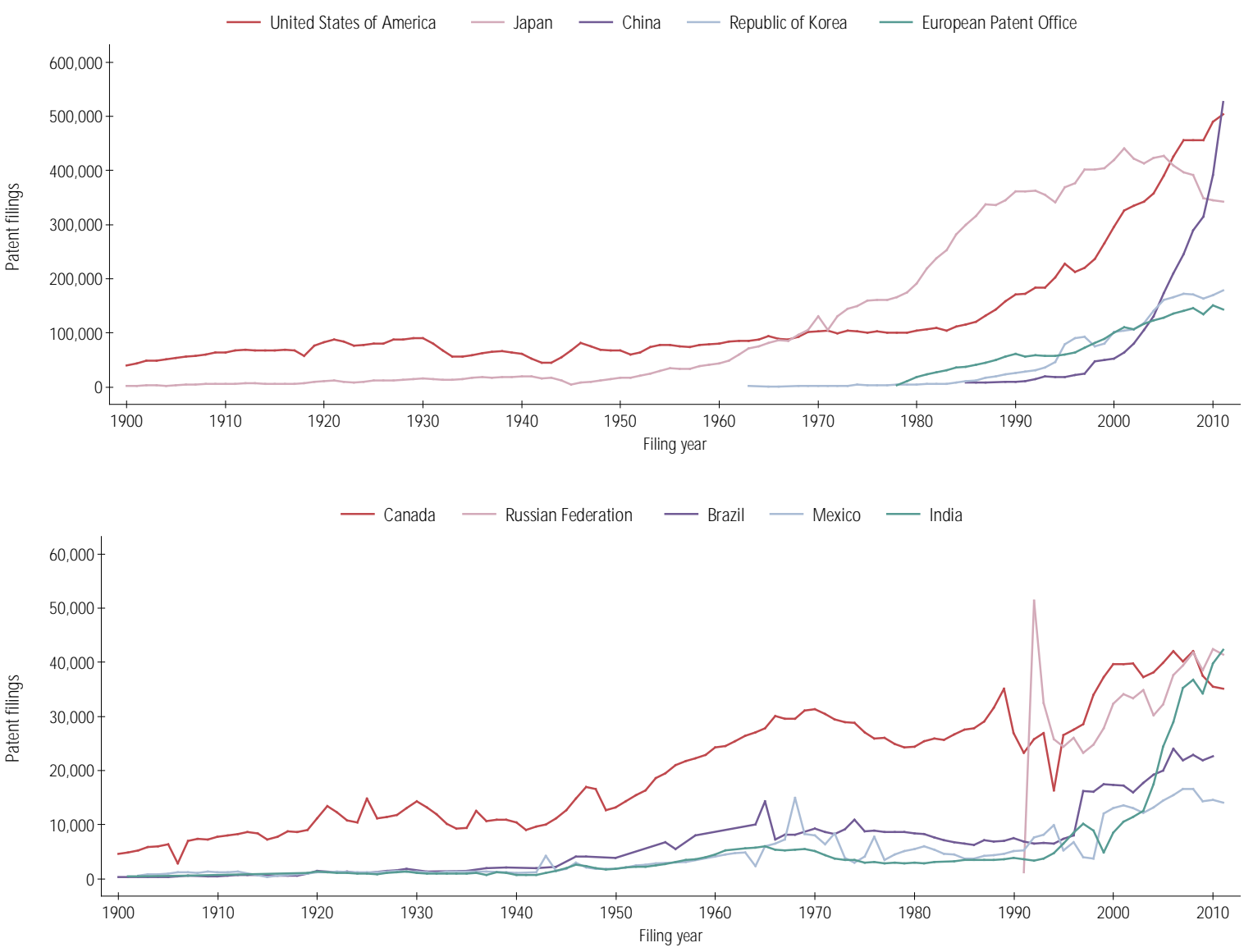

Source: WIPO Statistics Database

\section{LITERATURE REVIEW}

Most prior studies have focused on the growth of filings in the US (Kortum and Lerner, 1999; Hall and Ziedonis, 2001; Kim and Marschke, 2004; Hall, 2005) and China (Hu and Jefferson, 2009; Zhang, 2010). In addition, one study analyzes what is behind the increase in patent filings in Canada (Rafiquzzaman and Whewell, 1998).

The first prominent study to provide a detailed analysis of the patent surge in the US was Kortum and Lerner (1999). They tested three different hypotheses that might explain rapid filing growth: increased friendliness of courts, expanded technological opportunities, and changes in the management of research and development (R\&D). The first hypothesis was motivated by changes in the United States patent system - notably the creation of the Court of Appeals of the Federal Circuit - that Kortum and Lerner describe as favorable to patentees. They accordingly tested whether the increased probability of upholding a patent led to a higher proportion of potentially patentable inventions to be patented. The test of the second hypothesis - expanded technological opportunities - focused on whether the patent surge is confined to the high-technology area, particularly biotechnology and information technology. Finally, the test of the last hypothesis - changes in R\&D management centered on whether there was a movement towards applied R\&D activities that are likely to generate more patents. 
Kortum and Lerner employed statistics on total international patent applications, patent grant data by technology and applicant from the United States Patent and Trademark Office (USPTO), and aggregate R\&D expenditure statistics. By the process of elimination, they concluded that the "increase in patenting had been driven by changes in the management of innovation, involving a shift to more applied activities". 5 However, they acknowledged "...changes in the management of research may have had costs and benefits. The net impact on research productivity was potentially modest."

Kim and Marschke (2004) also studied the causes of the patent surge in the US using industry level data. They decompose aggregate data to analyze the effects of changes in $R \& D$ productivity, patent propensity, and $R \& D$ expenditure on patenting in different manufacturing industries. They found that increases in R\&D expenditure and R\&D productivity contributed to the surge over the 1983-1992 period. Three industries computers, electronics, and automobiles accounted for more than 60 percent of the total increase in patenting. Their evidence supports the findings of Kortum and Lerner (1999) that changes in the conduct of R\&D are an important factor in explaining the growth in patenting.

The findings of the study by Hall (2005) support the conclusion reached by Kim and Marschke (2004). Hall's analysis shows that the growth in patent applications in the US was mostly due to increased patenting by firms in "computing and electronics". She points to a major strategic shift towards patenting in those two sectors.

Hall and Ziedonis (2001) studied the patenting behavior of the semiconductors industry in the US and found evidence of a patent portfolio race induced by legislative changes. They argued that the patent surge occurred in response to an increased threat of holdup. Furthermore, they argued that firms have strong motivations for increased defensive - or strategic - patenting to enhance bargaining power for cross-licensing or in case of litigation. Indeed, several researchers have associated the growth in patenting to so-called strategic patenting behavior. While there appears to be no commonly agreed definition of this concept, it is generally used to describe patenting practices aimed at blocking other firms from patenting, preventing litigation and enlarging patent portfolios for cross-licensing negotiations (Blind, et. al. 2009). In the economic literature, the terminology appears to refer most frequently to a broad set of patenting practices and business strategies that arise in industries commercializing so-called complex technologies. ${ }^{6}$

\footnotetext{
${ }^{5}$ Data show that the US has become a significant source of patenting, but has not increased as a destination for patenting. Kortum and Lerner (1999) therefore rule out the friendly court hypothesis as the main factor for the surge in patenting. If this hypothesis were true, there should have been an increase in patenting by non-residents as well. All technology classes showed an increased rate of patenting rather than specific technologies; therefore, data also do not support the technological opportunities hypothesis as the driving force behind the surge in patenting.

${ }^{6}$ Harhoff et. al. (2007) define strategic patenting as "strategic use of the patent system [that] arises whenever firms leverage complementarities between patents in order to attain a strategic advantage over technological rivals. This behavior is anti-competitive if the main aim and effect of strategic use of the patent system is to decrease the efficiency of rival firms' production efforts." However, the authors state that this definition is not taken from any literature source and is subject to modification. See also Ziedonis (2004) and von Graevenitz, et. al. (2008).
} 
Strategic patenting has also been linked to the emergence of so-called patent thickets, with possibly harmful effects on innovation. Shapiro (2001) defines a patent thicket as "an overlapping set of patent rights requiring that those seeking to commercialize new technology obtain licenses from multiple patentees". To the extent that patent thickets increase transaction costs for innovators, they may undermine the incentive to innovate. Researchers have proposed solutions such as cross-licensing, patent pools, joint ventures and other cooperative mechanisms for minimizing transaction costs and holdup problems associated with patent thickets. ${ }^{7}$

As mentioned above, some studies have also explored the patent surge in China. Over the past two decades, China's innovation landscape has changed considerably. R\&D expenditure increased from 9 to 111 billion US dollars and R\&D intensity - defined as R\&D expenditure over Gross Domestic Product (GDP) - increased from 0.7 to 1.5 percent between 1990 and 2008. There also have been considerable inflows of foreign direct investments (FDI). Starting in the mid-1980s, China revised its patent law several times and subsequently saw strong filing growth, especially after the mid-1990s. ${ }^{8}$ Two studies have investigated China's patent surge (Hu and Jefferson, 2009; Zhang, 2010). Hu and Jefferson (2009) identified and tested five hypotheses for the causes of China's patent surge: policy reforms, increased R\&D investments, greater economic integration, economic reforms and changed industry composition. They concluded that no single factor can explain China's patent surge. However, amendments to the patent law in 2000 emerged as the main source of patenting growth in their study. FDI inflows also played an important role in encouraging Chinese firms to file more patents, but intensification of R\&D was not a major driving force behind the rapid growth in patenting. Zhang (2010) largely confirmed these results.

In the case of Canada, the study by Rafiquzzaman and Whewell (1998) concludes that two factors - patent policy changes and expanded technological opportunities - explain the growth in patenting; however, the latter factor offers a better empirical fit.

The above discussion suggests that no single factor explains why patent filings have grown over the past decades. Factors such as policy reforms, strategic patenting, patenting in new technology areas, changed management of R\&D, and economic integration have been identified as the main drivers.

\section{TREND IN WORLDWIDE PATENT FILINGS}

Analyzing worldwide patenting trends ideally requires a data source that covers all countries while offering bibliographical information on individual patents. To achieve this as best as possible, our study employs WIPO's patent family database comprised of a combination of the European Patent Office's (EPO) PATSTAT database together with PCT national phase entries stored in the WIPO Statistics Database. In particular, the patent family database contains information on individual records, allowing, for example, breakdowns by first and subsequent filings or by technology field. WIPO's patent family database provides comprehensive data up to $2008 .^{9}$ One drawback of this database is that it only captures patents that have been published; however, comparing patent family data to survey data that include unpublished filings suggests that the resulting bias is likely small - see Annex A1 for further details.

\footnotetext{
${ }^{7}$ However, despite the concern about patent thickets, Noel and Schankerman (2006) point out that the "econometric evidence on the effects of patent thickets is limited". A recent study (von Graevenitz et al. 2008) based on European Patent Office (EPO) data concluded that there are patent thickets in nine technology areas and their incidence has increased in recent years.

${ }^{8}$ The patent law came into force in 1985 and was amended twice (1992 and 2000). China joined the Patent Cooperation Treaty (PCT) in 1994.

${ }^{9} 2009$ data are available, but they are partial and incomplete, and are thus excluded from the analysis.
} 


\section{- What characterizes the surge in patent filings worldwide?}

Figure 2 depicts the trend in worldwide filings. It shows that growth in filings occurred over two periods. The first took place between 1983 and 1990 - henceforth referred to as the first surge; the second occurred between 1995 and 2008 - henceforth referred to as the second surge.$^{10}$ It is apparent that the magnitude of the increase for the second surge is higher than for the first one. Between 1995 and 2008, filings grew by 5.2 percent a year, compared to 3.7 percent for the 1983-1990 period. The growth rates for the two surge periods are higher than the overall annual growth rate of 2.9 percent between 1972 and 2008.

Figure 2: Worldwide patent filings: 1972-2009

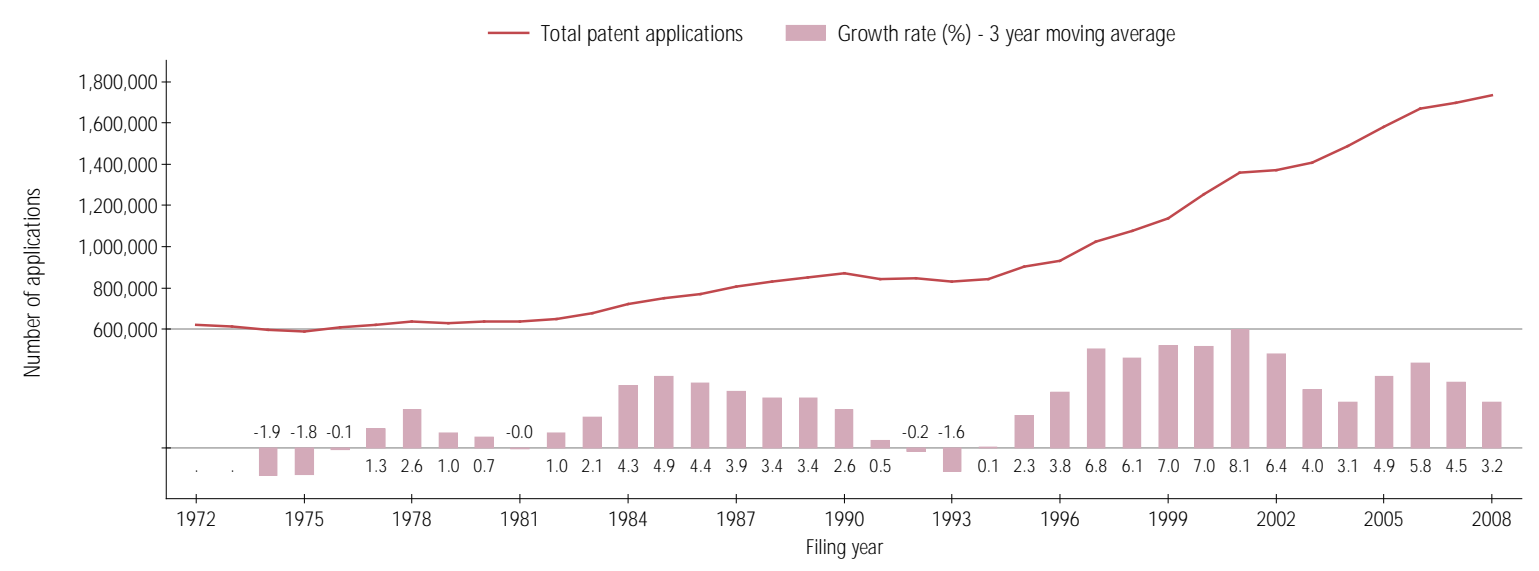

Source: WIPO Statistics Database

\section{- Where did the surge take place?}

Table 1 decomposes the change in total filings during the two surge periods by office. From 1983 to 1990, total filings grew by 29 percent, mostly due to rapid growth at the Japan Patent Office (JPO). ${ }^{11}$ The JPO accounted for 16.8 percentage points of the total growth, followed by the United States Patent and Trademark Office (USPTO, 8.1 percentage points) and the EPO (4.5 percentage points). From 1995 and 2008, total filings grew by 92.2 percent, mostly due to fast growth at the patent offices of China, the US, and the Republic of Korea. ${ }^{12}$ These three offices accounted for 65.7 percentage points of the total growth. The main difference between the first and the second surge is that the surge in worldwide filings in the 1980s was specific to one or at most three offices; the surge in filings over the 1995-2008 period was more broadly spread.

\footnotetext{
${ }^{10}$ Statistical tests confirm that there were structural breaks in the data series.

${ }^{11}$ The numbers refer to the change in volume and not in the growth rate.

12 One should not directly compare the changes in the volume of filings during the first and second surges (29 and 92.2 percent, respectively), because the number of years covered by the two periods differs ( 8 and 14 years, respectively).
} 
Table 1: Percentage point contribution of patent offices to change in total filing volumes

\begin{tabular}{|c|c|c|c|}
\hline Office & $\begin{array}{r}\text { Surge period: } \\
1983-1990\end{array}$ & Office & $\begin{array}{r}\text { Surge period: } \\
1995-2008\end{array}$ \\
\hline Total & 29.0 & Total & 92.2 \\
\hline Japan & 16.8 & China & 30.9 \\
\hline Unted States of America & 8.1 & Unted States of America & 19.9 \\
\hline European Patent Office & 4.5 & Republic of Korea & 14.9 \\
\hline Soviet Union & 1.5 & European Patent Office & 9.1 \\
\hline Republic of Korea & 1.0 & Russian Federation & 2.8 \\
\hline Canada & 1.0 & Japan & 2.4 \\
\hline \multirow[t]{2}{*}{ Others } & -3.9 & Germany & 2.0 \\
\hline & & Others & 10.2 \\
\hline
\end{tabular}

Note: Data represent changes in volume. For example, the number of filings in 1990 is 29 percent higher than in 1983 and Japan accounted for 16.8 percentage points of this 29 percent increase.

\section{Source: WIPO Statistics Database}

The worldwide trend masks important differences across countries. We therefore take a closer look at the filing activities at the top 15 offices. ${ }^{13}$ Annex A2 provides detailed figures for each of the top 15 offices. The graphs show that many offices experienced considerable increases in filings. We employ statistical tests and inspection of the data to determine the time periods that saw elevated filing growth. Based on this information, we separate the full sample period (1972-2008) into low- and high-growth periods for each office. ${ }^{14}$

Table 2 shows that there was considerable growth in filings during the high-growth period at ten offices. At the majority of them, the rise in filings started in the 1990s. Nonetheless, there are some exceptions. Japan saw high growth until the mid-1980s. ${ }^{15}$ The growth in filings at the USPTO started from 1984 onwards. The EPO experienced strong filing growth between 1979 and 1990. This reflects the fact that the EPO came into operation in 1978 and during the early period, starting from low volume, increases in the volume of filings generated high rates of growth. The increase in filings during the high-growth period was in excess of 4.6 percent a year for all ten offices. China and the Republic of Korea experienced doubledigit growth.

Five offices recorded a decline or only a slight increase in filings during the high-growth period (Table 2, Panel B). The filing declines in France, Italy and the United Kingdom and the low growth rate in Germany were arguably due to the creation of the EPO. Applicants opted to file at the EPO rather than at a national office if they wanted to obtain protection in other EPO member states.

\footnotetext{
${ }^{13}$ The top 15 offices were selected according to their total number of filings from 2000 to 2008 . Brazil and India do not appear in the list of top 15 offices, which is due to incomplete data in the EPO's PATSTAT database. Data submitted by the patent offices of Brazil and India show both of those offices to be in the list of top 15 in the world (see page 49 of the World Intellectual Property Indicators 2012).

${ }^{14}$ For example, the US data show a marked pick-up in filing activity from 1984 onwards. For this reason, the US data are divided into the 1972-1983 and the 1984-2008 sample periods.

15 Since 1988, the number of applications received by the JPO has been fairly stable (growing at 0.8 percent a year). This could be due to the rule change at the JPO in 1988 that made it possible to include multiple claims in a single application.
} 
Table 2: Filings growth at the top 15 patent offices (average annual growth)

Panel A: Offices with high-growth in filings

\begin{tabular}{lrrrr}
\hline \multicolumn{1}{c}{ Office } & $\begin{array}{r}\text { Growth rate } \\
(\%)\end{array}$ & $\begin{array}{r}\text { Low-growth } \\
\text { period }\end{array}$ & $\begin{array}{r}\text { Growth rate } \\
(\%)\end{array}$ & $\begin{array}{r}\text { High-growth } \\
\text { period }\end{array}$ \\
\hline Australia & 1.4 & $1972-1997$ & 6.0 & $1999-2008$ \\
\hline China & 4.3 & $1985-1991$ & 21.6 & $1992-2008$ \\
\hline European Patent Office & 2.6 & $1991-1996$ & 16.4 & $1979-1990$ \\
& & & 6.2 & $1997-2008$ \\
\hline Israel & 1.8 & $1972-1994$ & 4.8 & $1995-2008$ \\
\hline Japan & 0.7 & $1988-2008$ & 7.1 & $1972-1987$ \\
\hline Mexico & 3.4 & $1976-1990$ & 9.7 & $1996-2008$ \\
\hline Republic of Korea & & & 18.8 & $1976-1994$ \\
& & & 12.9 & $1995-2008$ \\
\hline Russian Federation & 2.5 & $1993-2001$ & 4.7 & $2002-2008$ \\
\hline South Africa & -0.5 & $1972-1994$ & 4.6 & $1995-2006$ \\
\hline Unted States of America & -2.5 & $1972-1983$ & 6.7 & $1984-2008$ \\
\hline
\end{tabular}

Panel B: Offices with low-growth or decrease in filings

\begin{tabular}{lrrrr} 
& Office & $\begin{array}{r}\text { Growth rate } \\
(\%)\end{array}$ & $\begin{array}{r}\text { Low-growth } \\
\text { period }\end{array}$ & $\begin{array}{r}\text { Growth rate } \\
(\%)\end{array}$ \\
\hline Canada & -0.5 & $1972-1988$ & 2.5 & $\begin{array}{r}\text { High-growth } \\
\text { period }\end{array}$ \\
\hline France & -5.7 & $1972-1992$ & 0.5 & $1993-20008$ \\
\hline Germany & -2.8 & $1972-1995$ & 2.8 & $1996-2008$ \\
\hline Italy & -11.0 & $1972-1986$ & -0.3 & $1987-2008$ \\
\hline United Kingdom & -4.8 & $1972-1982$ & -1.3 & $1983-2008$ \\
\hline
\end{tabular}

Source: WIPO Statistics Database

\section{- Which origins are behind the surge?}

Having established which offices account for the surge, it is equally interesting to ask which applicant origins have seen the fastest filing growth. We define origin as the country of residence of the first-named applicant. To the extent that the propensity of resident applicants to seek patent protection abroad differs across countries, filing growth by origin will look different from filing growth by office. In addition, the breakdown by origin better captures the filing activity of European applicants that may either file at their national office or at the EPO.

Similar to Table 1, Table 3 shows the contribution of different countries to the change in overall filings. The main source of filing growth during the first surge were Japanese applicants, mirroring the breakdown by offices (Table 1). They accounted for 18.9 percentage points of the total growth (29 percent). The combined contribution of German and US applicants stood at 8.5 percentage points. For the second surge, applicants from China contributed the most (19.4 percentage points) to the overall growth (92.2 percent), followed by the US (18.5 percentage points), the Republic of Korea (14.3), and Japan (11.5). Note that China was the largest source of filing growth for both office and origin data. As in the case of the breakdown by offices, the surge in filings over the 1995-2007 period shows greater geographic diversity. 
Table 3: Percentage point contribution of applicant origins to the change filing volumes

\begin{tabular}{|c|c|c|c|}
\hline Origin & $\begin{array}{r}\text { Surge period: } \\
1983-1990\end{array}$ & Origin & $\begin{array}{r}\text { Surge period: } \\
1995-2008\end{array}$ \\
\hline Total & 29.0 & Total & 92.2 \\
\hline Japan & 18.9 & China & $\overline{19.4}$ \\
\hline United States of America & 7.3 & United States of America & 18 \\
\hline Germany & 1.2 & Republic of Korea & 14. \\
\hline \multirow[t]{7}{*}{ Others } & 1.7 & Japan & 11 \\
\hline & & Germany & 5 \\
\hline & & Russian Federation & 2 \\
\hline & & France & 2 \\
\hline & & Canada & 1 \\
\hline & & Switzerland & 1 \\
\hline & & Others & 16. \\
\hline
\end{tabular}

Note: Data represent change in volume. For example, the number of filings in 1990 was 29 percent higher than in 1983. Applicants from Japan accounted for 18.9 percentage points of the total change.

Source: WIPO Statistics Database

Table 4: Filings growth for the top 15 origins (average annual growth)

Panel A: Origin with high-growth in filings

\begin{tabular}{lrrrr}
\hline Origin & $\begin{array}{r}\text { Growth rate } \\
(\%)\end{array}$ & $\begin{array}{r}\text { Low-growth } \\
\text { period }\end{array}$ & $\begin{array}{r}\text { Growth rate } \\
(\%)\end{array}$ & $\begin{array}{r}\text { High-growth } \\
\text { period }\end{array}$ \\
\hline Canada & 3.1 & $1972-1996$ & 6.0 & $1997-2008$ \\
\hline China & 10.2 & $1985-1998$ & 31.9 & $1999-2008$ \\
\hline Finland &.. &.. & 6.0 & $1972-1992$ \\
&.. &.. & 5.6 & $1993-2008$ \\
\hline France & -0.8 & $1972-1995$ & 3.7 & $1996-2008$ \\
\hline Germany & -0.5 & $1972-1996$ & 3.2 & $1997-2008$ \\
\hline Italy & -0.8 & $1972-1993$ & 3.3 & $1994-2008$ \\
\hline Japan & 1.8 & $1995-2008$ & 6.6 & $1972-1990$ \\
\hline Netherlands & -2.4 & $1972-1995$ & 6.9 & $1996-2008$ \\
\hline Republic of Korea &.. &.. & 23.6 & $1981-1990$ \\
&.. &.. & 16.9 & $1991-2008$ \\
\hline Russian Federation &.. & & 9.6 & $1994-2008$ \\
\hline Sweden & 0.3 & $1972-1993$ & 4.5 & $1994-2008$ \\
\hline Switzerland & -2.3 & $1972-1994$ & 5.1 & $1995-2008$ \\
\hline Unted States of America & -3.2 & $1972-1983$ & 4.8 & $1984-2008$ \\
\hline
\end{tabular}

Panel B: Origin with low-growth in filings

\begin{tabular}{lrrrr}
\hline \multirow{2}{*}{ Origin } & $\begin{array}{r}\text { Growth rate } \\
(\%)\end{array}$ & $\begin{array}{r}\text { Low-growth } \\
\text { period }\end{array}$ & $\begin{array}{r}\text { Growth rate } \\
(\%)\end{array}$ & $\begin{array}{r}\text { High-growth } \\
\text { period }\end{array}$ \\
\hline Australia & 0.4 & $1972-1992$ & 1.3 & $1994-2008$ \\
\hline United Kingdom & -0.9 & $1972-1996$ & 1.3 & $1997-2008$ \\
\hline
\end{tabular}

Source: WIPO Statistics Database

Annex A3 provides filing trends by country of origin for the top 15 origins. ${ }^{16}$ Again, we separate the sample period (1972-2008) into low- and high- growth periods. Table 4 provides average annual growth rates for both periods for each office. All origins saw an increase in filings during the high-growth period. Applications from China and the Republic of Korea experienced the fastest growth. Australia and the United Kingdom stand out with relatively modest filing growth over the high-growth period.

\footnotetext{
${ }^{16}$ The top 15 origins are selected according to their total number of filings from 2000 to 2008 .
} 


\section{WHAT MIGHT EXPLAIN THE GROWTH IN WORLDWIDE PATENT FILINGS}

One can broadly distinguish among three factors that might explain the surge in patenting worldwide: multiple filings for the same invention, changes in $f$ the patent yield, and patenting in new technological areas. Multiple filings of the same invention as the driver behind the patent surge is a new hypothesis not considered in the prior literature. Previous studies have investigated the possibility that changes in patent yield contributed to the surge; however, we propose a new measure of this yield that arguably better reflects inventive output. Finally, we also explore whether any particular areas of technology can account for the global surge.

\section{- Are there more inventions or is it simply the case of multiple filings?}

Figure 3 provides a breakdown of worldwide patent applications by type of filings - first and subsequent filings. ${ }^{17}$ First filings are closely associated with the idea of a new invention, whereas subsequent filings are linked to earlier filings and thus do not introduce a new invention. If the growth in filings is due to first filings, then the patent surge would reflect an invention surge. However, if subsequent filings are the source of growth then the surge in filings is due to multiple filings for the same invention.

Table 5 reports the breakdown of the growth rate in different periods by first and subsequent filings as well as their respective shares. In the first surge period (1983-1990), first filings (3.9 percent) saw a higher growth rate than subsequent filings (3.3 percent). The opposite holds for the second surge period (1995-2008) - first filings (4.3 percent) grew more slowly than subsequent filings (6.4 percent).

Figure 3: Worldwide filings by type of filings

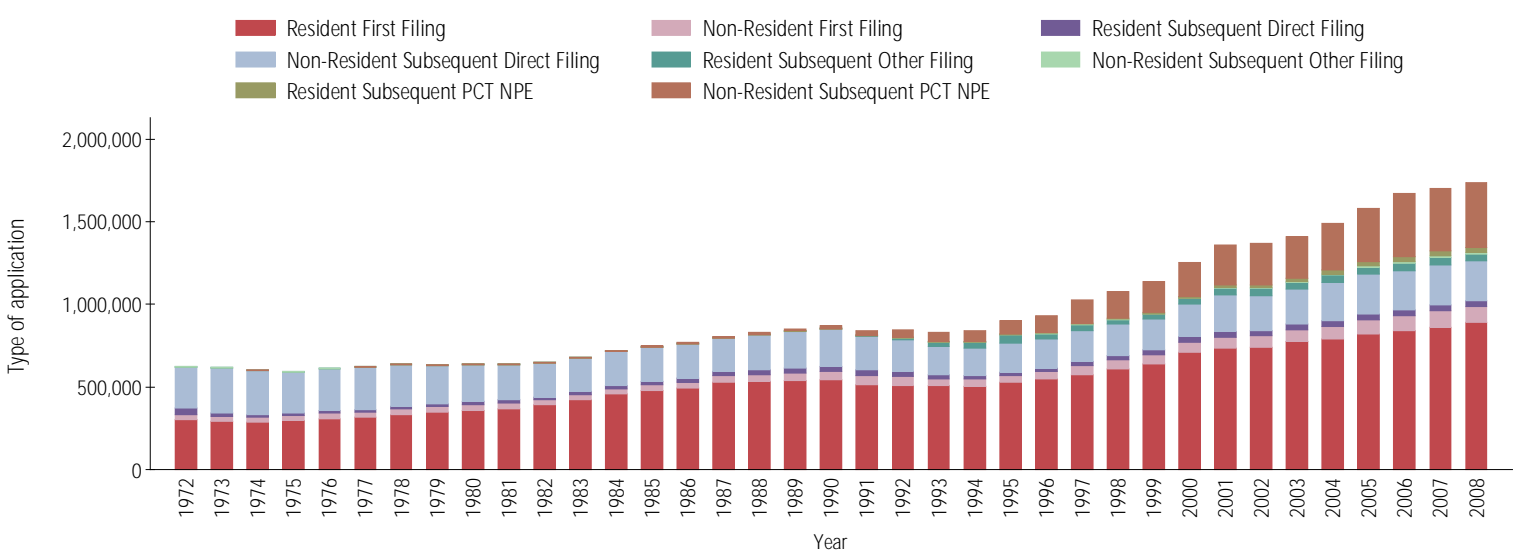

Source: WIPO Statistics Database

\footnotetext{
${ }^{17}$ To obtain patent protection, applicants need to file an application describing a new invention at a patent office. The first time they do this, the application is called a "first filing"; the next time it is filed and is linked to the previous filing, it is called a "subsequent filing". There are many reasons why applicants would file subsequent applications. For example, (a) an improvement has been made to the initial invention, so they file another one to add these improvements; (b) protection is sought in other countries, thus necessitating the filing of applications at foreign offices, and; (3) the applicant wishes to keep the application "alive" in certain offices through a "continuation" or "continuation-in-part". A PCT application can be either a first or subsequent filing. If it has no priority claim, it is considered a first filing; otherwise it is a subsequent filing. A PCT national phase entry is a subsequent filing, as it is always associated with a PCT filing.
} 
Table 5: Growth rate and share of first and subsequent filings

\begin{tabular}{|c|c|c|c|c|c|c|c|c|c|c|}
\hline \multirow{2}{*}{ Filings type } & \multicolumn{5}{|c|}{ Average annual growth rate (\%) } & \multicolumn{5}{|c|}{ Share of first and subsequent filings (\%) } \\
\hline & $1972-82$ & $1983-90$ & $1991-94$ & 1995-08 & 1972-2008 & $1972-82$ & $1983-90$ & $1991-94$ & 1995-08 & $1972-2008$ \\
\hline Total & 0.4 & 3.7 & 0.1 & 5.2 & 2.9 & 100.0 & 100.0 & 100.0 & 100.0 & 100.0 \\
\hline First Filings & 2.5 & 3.9 & -1.2 & 4.3 & 3.1 & 57.9 & 68.7 & 66.3 & 59.2 & 61.3 \\
\hline Subsequent Filings & -2.4 & 3.3 & 2.8 & 6.4 & 2.7 & 42.1 & 31.3 & 33.7 & 40.8 & 38.7 \\
\hline
\end{tabular}

Source: WIPO Statistics Database

Figure 4 shows the contribution of first and subsequent filings to the overall growth during the two surge periods. During the first surge, first filings accounted for 70.9 percent of the total growth and subsequent filings for the remainder. In other words, the first surge was mainly due to new inventions. In contrast, first and subsequent filings equally accounted for the total growth over the second surge period. In other words, both multiple filings and new inventions contributed to the second surge.

Figure 4: Contribution of first and subsequent filings to total growth

First surge period: $1983-1990$

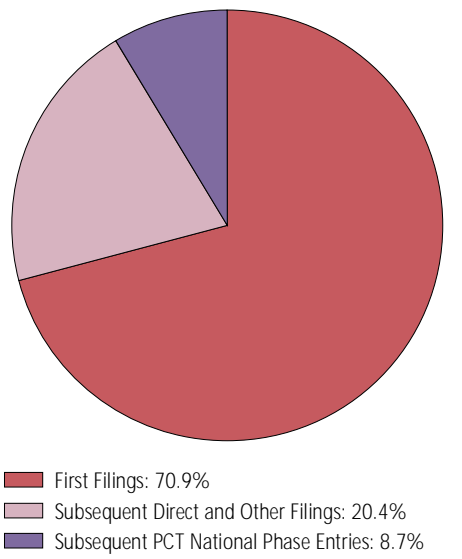

Second surge period: $1995-2008$

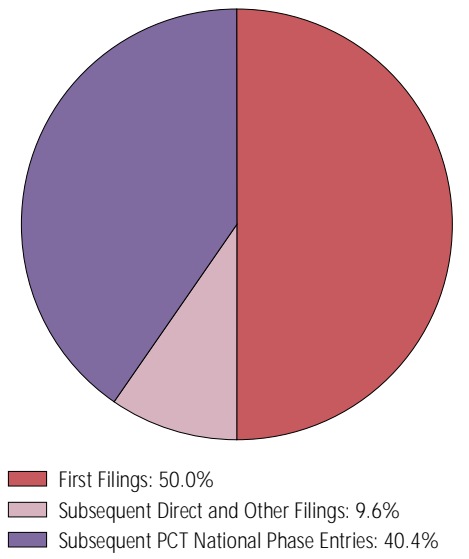

Source: WIPO Statistics Database

Subsequent filings mostly represent filings abroad. While a detailed analysis of what has driven increased filings abroad is beyond the scope of this study, rapidly growing international commerce - or more colloquially "globalization" - is likely to be a key explanatory factor. Overall, the share of subsequent filings grew from 31.3 percent in 19831990 to 40.8 percent in 1995-2007 (Table 5). Within the category of subsequent filings, there has been an increase in the use of the Patent Cooperation Treaty (PCT) system. In fact, PCT national phase entries accounted for most of the growth in subsequent filings during the second surge period. Again, globalization is likely the main driver of increasing PCT use, though growing PCT membership may have also played a role.

Figure 5 depicts the contribution of first and subsequent filings to total growth for the top offices over the previously identified high-growth periods. In China, Germany, Japan, the Republic of Korea, and the Russian Federation, first filings - approximating new inventions were the main source of filing growth. For example, more than 90 percent of the total growth in Japan was due to first filings. In seven offices, multiple filings were the main factor behind the surge. For example, almost all the growth in Mexico was due to multiple filings. 
Figure 5: Relative contributions of first and subsequent filings to filing growth by office

Growth in filings is mostly due to new inventions

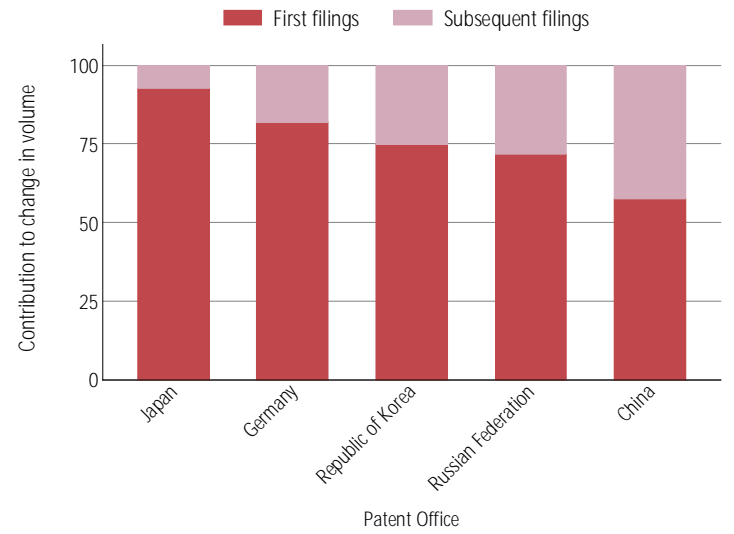

Growth in filings is mostly due to multiple filings

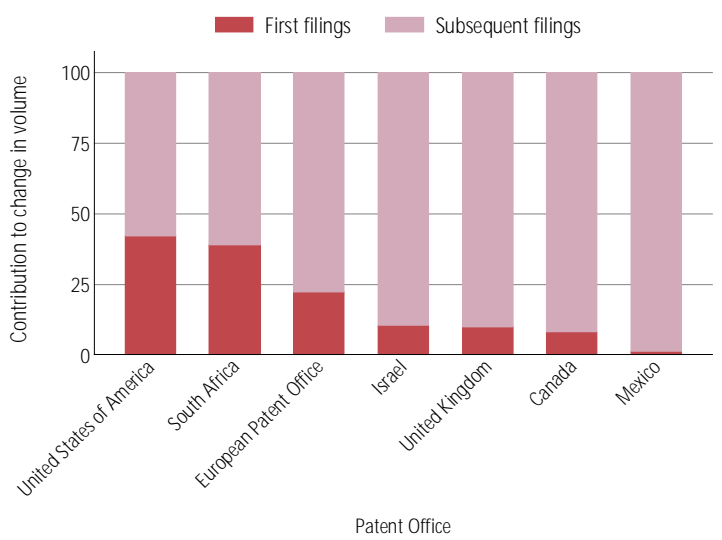

Note: The list of offices and the high-growth sample period reported here are the same as in table 2 . We exclude Australia, France and Italy from the graph because they saw considerable drops in either first and/or subsequent filings.

Source: WIPO Statistics Database

Figure 6 shows the contribution of first and subsequent filings to total growth by country of origin, again focusing on the high-growth periods. New inventions were the main factor behind growth in filings originating from China, Japan, the Republic of Korea and the Russian Federation. For those countries, the contribution of multiple filings was small. This reflects the fact that applicants from these countries mostly filed for protection in their respective domestic markets. Subsequent filings were the largest contributor to total growth in filings for 10 countries. For example, 93 percent of total growth in filings by UK residents was due to subsequent filings, and first filings accounted for only 7 percent of total growth. In the case of the US, the contribution of first (48.5 percent) and subsequent (51.5 percent) filings to total growth was more evenly balanced.

Figure 6: Contribution of first and subsequent filings to filing growth by origin

Growth in filings is mostly due to new inventions

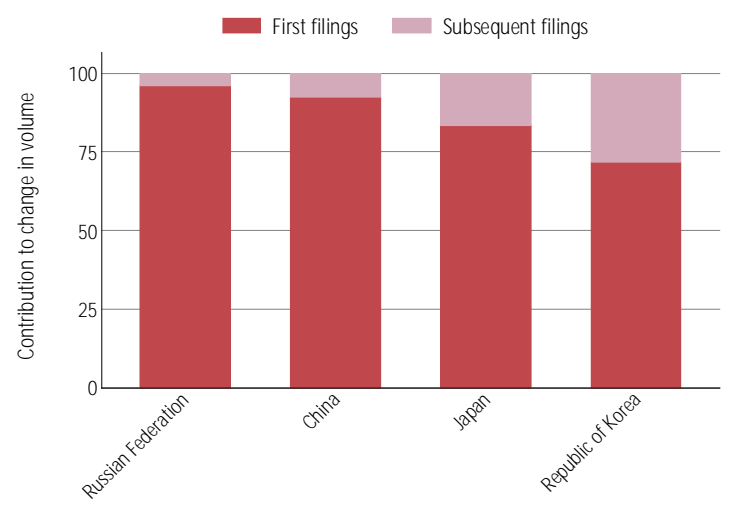

Origin
Growth in filings is mostly due to multiple filings

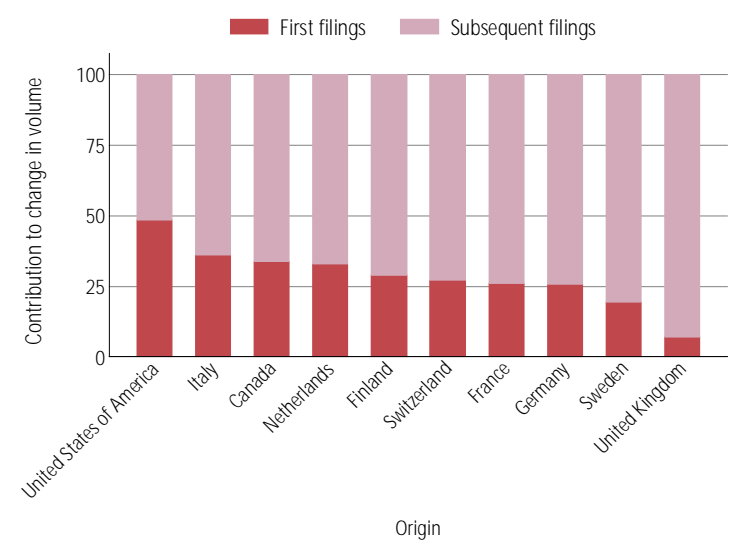

Note: The list of countries and the high-growth sample period reported here are the same as in table 4 . We exclude Australia from the graph because it saw a considerable drop in either first filings and/or subsequent filings.

Source: WIPO Statistics Database 


\section{- Can a growing patent yield explain the surge in filings?}

Figure 7 shows the trend in the global patent yield - defined here as first filings over constant dollar business sector R\&D expenditure. ${ }^{18}$ Contrasting the surge in patent filings, the patent yield has been on a continuous downward trend. In other words, shifts in the global patent yield cannot account for the worldwide patent surge.

We use data on first filings to derive the patent yield rather than resident filings as some of the prior literature has done (Jaffe 2000; Kim and Marschke 2004). This is arguably a better measure of the patent yield. Some inventors may not seek a patent in their home office, whereas others may file two or more patents for the same invention at home. Indeed, measuring the patent yield based on resident filings may be misleading for some countries. This is illustrated in figure 8 which depicts the patent yield for selected origins based on first filings and resident filings. The measure based on resident filings shows a downward trend for the Netherlands and Switzerland. However, it shows an upward trend when using first filings. This is due to the preference of Dutch and Swiss applicants to file abroad without first filing at their respective domestic patent offices. For the US, the patent yield based on resident filings exceeds the patent yield based on first filings. This is due to the inclusion of subsequent domestic filings - for example, continuations in part - in the former measure.

Reflecting figure 7 , the patent yield for the majority of origins follows a downward trend. Notable exceptions are the US, China (only for recent years) and the Netherlands. The patent yield of the US increased during the 1986-2005 period but has fallen since then. In the case of China, the upward trend in the patent yield is a recent phenomenon. The Netherlands has seen a slight upward trend in the patent yield since the mid-1990s.

\footnotetext{
${ }^{18}$ R\&D data are lagged by one year.
} 
Figure 7: Worldwide patent yield

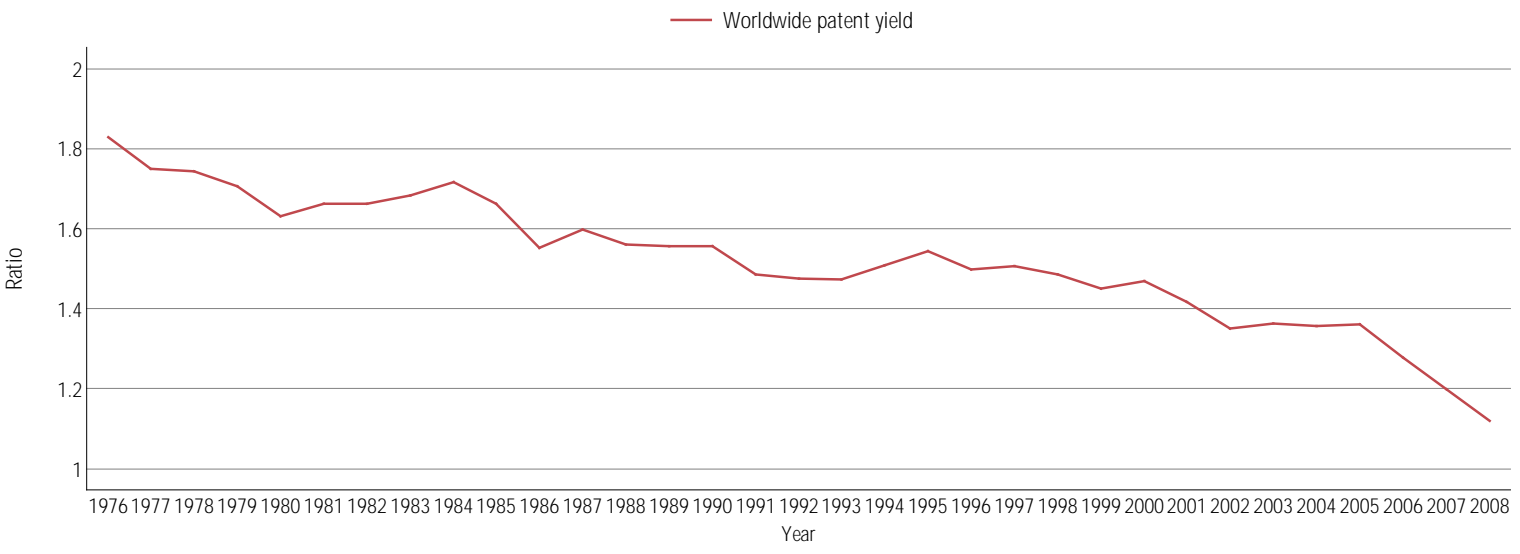

Note: The graph is based on data for the following country of origins: Australia, Austria, Belgium, Canada, Denmark, Finland, France, Germany, Ireland, Italy, Japan, Netherlands, New Zealand, Norway, Portugal, Spain, Sweden, Switzerland, United Kingdom and United States of America. It includes all the main R\&D spenders except China, the Republic of Korea, and the Russian Federation because of insufficient data. R\&D data refer to business sector R\&D expenditure in constant 2005 PPP dollars. Patent filing data refer to first filing data.

Source: WIPO Statistics Database, and OECD and UNESCO R\&D Databases

Figure 8: Patent yield for selected origins

\section{Belgium}

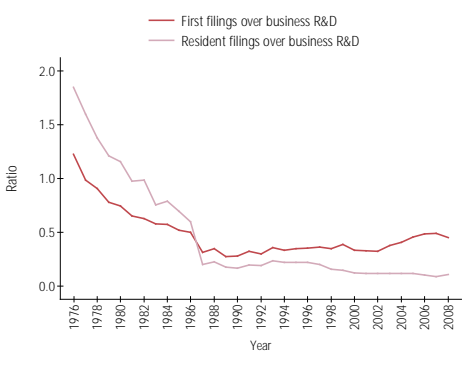

Denmark

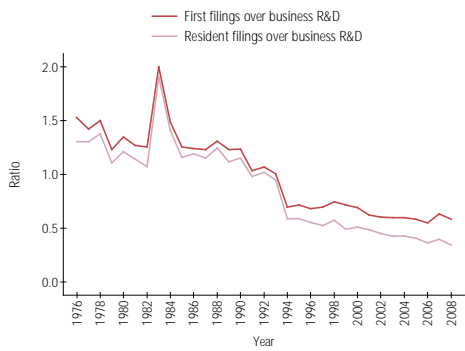

Italy

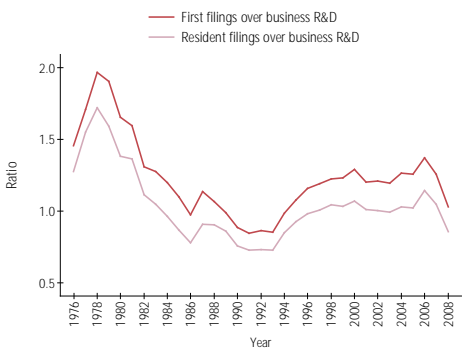

\section{Canada}

- First flings over business R\&D

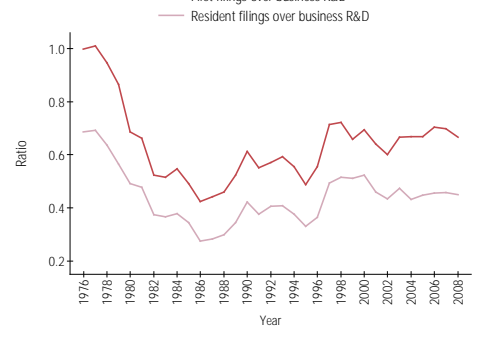

France

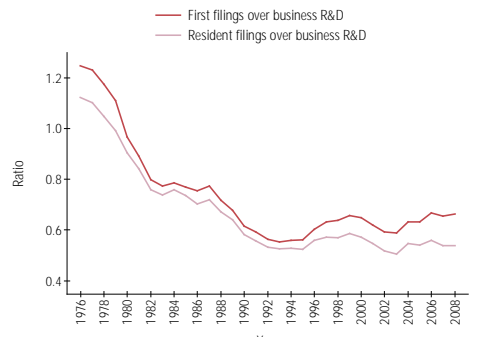

Japan

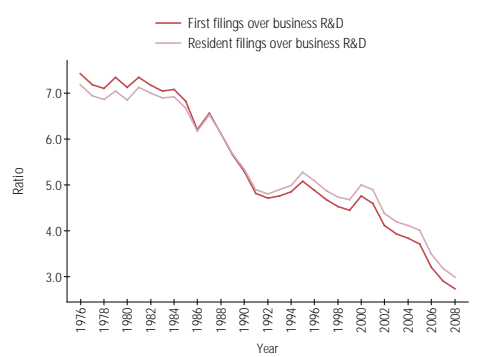

\section{China}

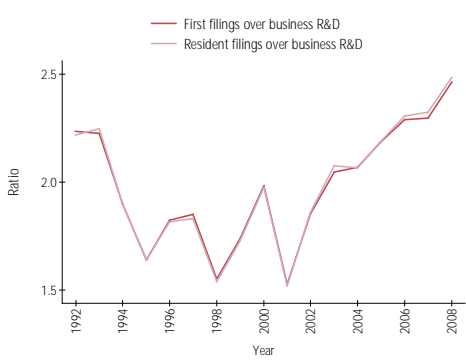

Germany

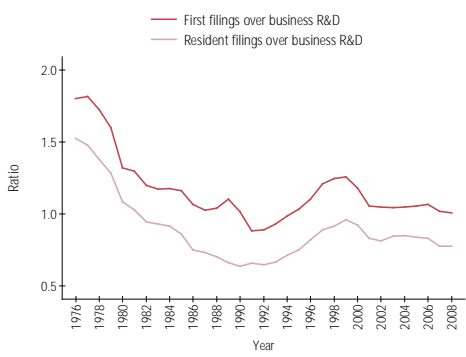

\section{Netherlands}

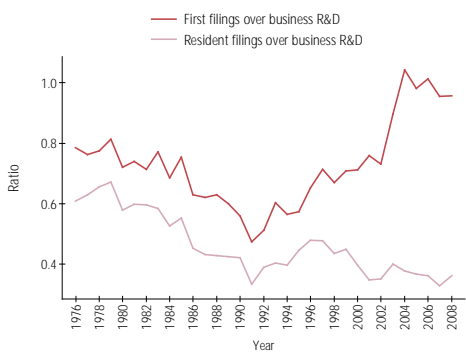


Republic of Korea

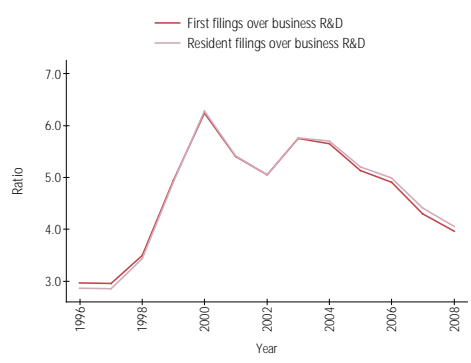

Switzerland

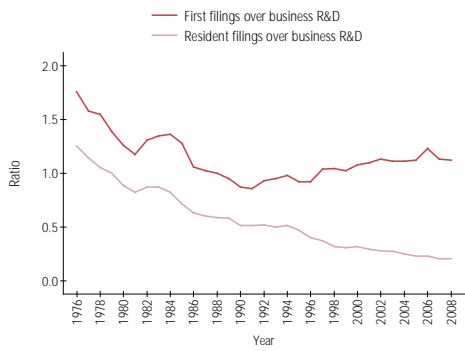

Russian Federation

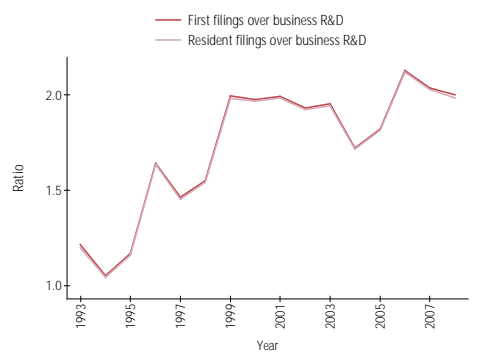

United Kingdom

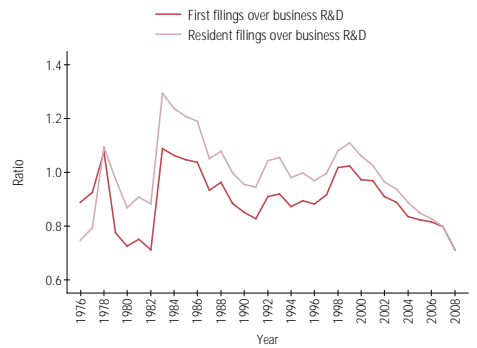

Sweden

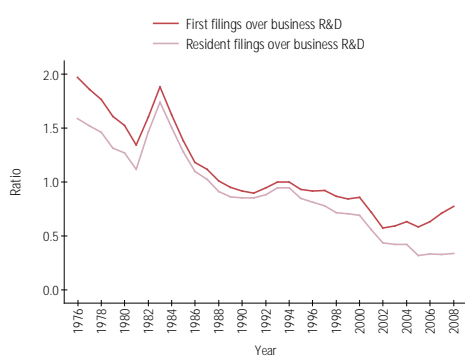

United States of America

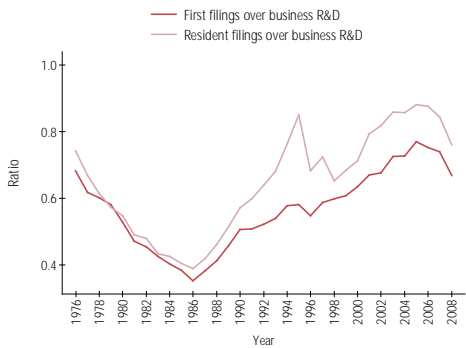

Note: R\&D data refer to business sector R\&D expenditure in constant 2005 PPP dollars.

Source: WIPO Statistics Database, and OECD and UNESCO R\&D Databases

Looking at the economy-wide trend in the patent yield hides varying experiences across industries. Unfortunately, evaluating how the patent yield has evolved at the industry level is difficult, as patent data are broken down by technology fields which do not easily match definitions of different industries. Figure 9 depicts patent yield trends for four sectors for which we could "approximately" match patent data by field of technology with R\&D data by industry. Depending on the category, the comparison is based on data from up to 16 countries. All four categories show an upward trend in the patent yield starting from the late 1990s. The steepest increase occurred in the electrical machinery, computer and audiovisual technology category. ${ }^{19}$ Clearly, figure 9 focuses on industries with an increasing patent yield trend. Since the trend across all industries is negative (see figure 7), the trend must also be negative for at least some of the industries that, due to data limitations, could not be included in figure 9 .

\footnotetext{
${ }^{19}$ Figure 10 shows an increasing patent yield trend for pharmaceuticals, starting in the mid-1990s. This contrasts with Hall and Ziedonis (2001) who find a declining trend in this industry. However, their study only focused on the US. In addition, it employed a different methodology in matching patent to R\&D data; in particular, it identified the companies behind the patent applicants and then collected R\&D data for these companies.
} 
Figure 9: Patent yield in selected industries

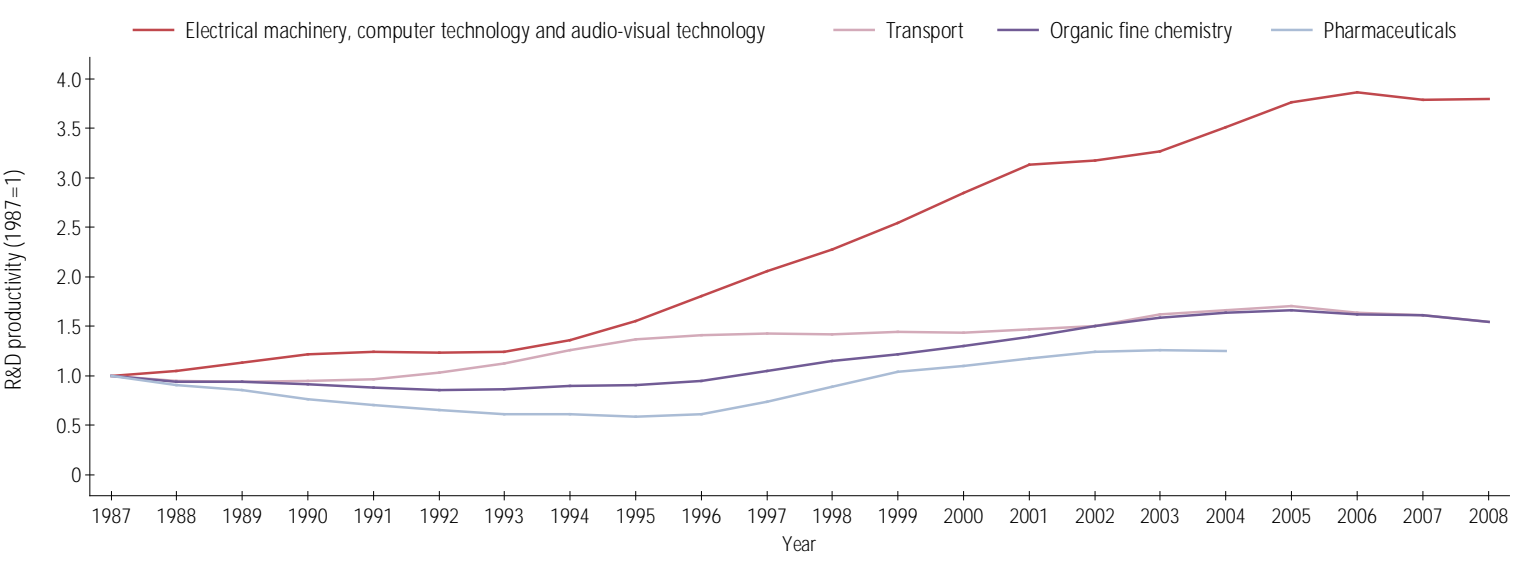

Note: The IPC-technology concordance table (available at: www.wipo.int/ipstats/en) was used to convert IPC symbols into corresponding fields of technology. The graph includes the following countries: Australia, Belgium, Canada, Denmark, France, Germany, Ireland, Italy, Norway, Spain, the United Kingdom and the US. In addition: Iceland is included for electrical machinery, organic fine chemistry and pharmaceuticals; Japan is included for organic fine chemistry, pharmaceuticals and transport; the Netherlands is included for organic fine chemistry and pharmaceuticals; Sweden is included for pharmaceuticals; and Portugal and Turkey are included for transport. R\&D data availability is limited to the selection of origins. For example, China and the Republic of Korea, two large patent filing countries, were not included due to insufficient data. Generally, there is no one-to-one match between fields of technology and industrial sectors. The four industries included in the figure have a close but not perfect correspondence between patents and R\&D.

Source: WIPO Statistics Database and OECD Database

\section{- Can growth in specific technologies explain the surge in filings?}

As discussed in section II above, a number of studies have attributed the patent surge to certain high-tech industries. Table 7 shows the growth rate for the top 20 fields of technology. ${ }^{20}$ From 1995 to 2008 , digital communication saw the fastest average annual growth (14.9 percent), followed by pharmaceuticals (9.3 percent), computer technology (9.2 percent), semiconductors (7.8 percent) and medical technology (7.4 percent).

The average annual growth rates shown in Table 7 mask the relative weight of different technologies in overall patenting activity. Table 8 therefore provides information on the contribution of each technology field to total filing growth between 1995 and 2008. Computer technology (9.5 percentage points) accounted for the largest share of the total overall increase (92.2 percent). Electrical machinery, digital communication, pharmaceuticals and semiconductors each contributed between 5.2 and 6.3 percentage points.

Overall, the figures presented in Table 8 suggest that no single field of technology can account for the worldwide patent surge. Three of the broadly defined information and communication technologies (ICTs) - in particular, computer technology, digital communication, and telecommunications - were important sources of growth, but even their combined contribution accounted for only around a fifth of the overall increase.

Table 8 also reports the contribution of first and subsequent filings to overall growth for the different technology fields. For a number of fields, first filings accounted for the majority of growth in total filings between 1995 and 2008. The contribution of first filings growth to total growth was largest for food chemistry and IT methods for management. In contrast, the contribution of subsequent filings to overall growth was largest for optics and surface technology.

\footnotetext{
${ }^{20}$ We use WIPO's IPC-Technology concordance table to classify data by technology. There are 35 technologies, but we focus on the top 20 technologies based on average number of filings during the 1995-2008 period.
} 
Table 7: Filing growth rate by technology field

\begin{tabular}{lrrrr}
\hline \multicolumn{1}{c}{ Technology } & \multicolumn{3}{c}{ Average annual growth rate (\%) } \\
\hline Total & 1972-1982 & 1983-1990 & 1991-1994 & 1995-2008 \\
\hline Digital communication & $\mathbf{0 . 4}$ & $\mathbf{3 . 7}$ & $\mathbf{0 . 1}$ & $\mathbf{5 . 2}$ \\
\hline Pharmaceuticals & 5.0 & 9.2 & 4.6 & $\mathbf{1 4 . 9}$ \\
\hline Computer technology & 8.3 & 5.4 & 5.8 & 9.3 \\
\hline Semiconductors & 6.1 & 10.3 & -5.5 & 9.2 \\
\hline Medical technology & 8.6 & 8.4 & -7.4 & 7.8 \\
\hline Electrical machinery, apparatus, energy & 5.4 & 6.3 & 6.4 & 7.4 \\
\hline Measurement & 1.4 & 1.1 & 0.6 & 6.1 \\
\hline Telecommunications & 2.2 & 2.5 & -4.9 & 5.9 \\
\hline Engines, pumps, turbines & 4.2 & 8.1 & -0.5 & 5.8 \\
\hline Furniture, games & 4.2 & 0.1 & -2.3 & 5.6 \\
\hline Audio-visual technology & -1.3 & 4.8 & 9.2 & 5.3 \\
\hline Transport & 5.8 & 6.5 & -2.2 & 4.8 \\
\hline Organic fine chemistry & -0.3 & 3.3 & 3.6 & 4.7 \\
\hline Basic materials chemistry & -1.9 & 0.9 & 1.4 & 4.0 \\
\hline Mechanical elements & 0.9 & 1.3 & 1.0 & 4.0 \\
\hline Optics & -0.6 & 0.3 & 1.6 & 3.9 \\
\hline Machine tools & 3.6 & 7.6 & -2.2 & 3.9 \\
\hline Civil engineering & 0.4 & -0.2 & -2.7 & 3.5 \\
\hline Other special machines & 0.3 & 2.0 & 4.8 & 2.5 \\
\hline Handling & -0.3 & 2.9 & -0.4 & 2.5 \\
\hline Wiros & -0.4 & 1.3 & 3.3 & 2.2 \\
\hline
\end{tabular}

Note: WIPO's IPC-Technology concordance table is used to classify the data by fields of technology.

Source: WIPO Statistics Database

Table 8: Contribution of technology fields to the change in filing volume, $1995-2008$

\begin{tabular}{lrrr}
\hline \multicolumn{1}{c}{ Technology } & $\begin{array}{r}\text { Change in } \\
\text { total volume }\end{array}$ & $\begin{array}{r}\text { First filing } \\
\text { contribution }\end{array}$ & $\begin{array}{r}\text { Subsequent } \\
\text { filing } \\
\text { contribution }\end{array}$ \\
\hline Total & 92.2 & 46.1 & 46.1 \\
\hline Computer technology & 9.5 & 5.0 & 4.6 \\
\hline Electrical machinery, apparatus, energy & 6.3 & 3.1 & 3.2 \\
\hline Digital communication & 5.7 & 3.0 & 2.7 \\
\hline Pharmaceuticals & 5.6 & 2.5 & 3.1 \\
\hline Semiconductors & 5.2 & 2.3 & 2.9 \\
\hline Medical technology & 4.8 & 2.1 & 2.7 \\
\hline Measurement & 4.1 & 2.2 & 1.9 \\
\hline Audio-visual technology & 4.1 & 1.6 & 2.4 \\
\hline Telecommunications & 3.4 & 1.8 & 1.6 \\
\hline Transport & 3.4 & 1.7 & 1.6 \\
\hline Optics & 2.9 & 1.1 & 1.7 \\
\hline Engines, pumps, turbines & 2.5 & 1.2 & 1.3 \\
\hline Furniture, games & 2.3 & 1.4 & 0.9 \\
\hline Organic fine chemistry & 2.3 & 1.2 & 1.1 \\
\hline IT methods for management & 2.2 & 1.5 & 0.7 \\
\hline Biotechnology & 2.1 & 1.2 & 0.9 \\
\hline Mechanical elements & 1.9 & 0.9 & 1.0 \\
\hline Basic materials chemistry & 1.8 & 0.9 & 0.9 \\
\hline Food chemistry & 1.8 & 1.4 & 0.4 \\
\hline Surface technology, coating & 1.6 & 0.6 & 0.9 \\
\hline Civil engineering & 1.6 & 0.8 & 0.8 \\
\hline Machine tools & 1.5 & 0.8 & 0.8 \\
\hline Control & 1.5 & 0.9 & 0.6 \\
\hline Materials, metallurgy & 1.5 & 0.9 & 0.6 \\
\hline Other consumer goods & 1.4 & 0.8 & 0.6 \\
\hline Others & 11.5 &.. &.. \\
\hline C-Technogy concorang & & & \\
\hline
\end{tabular}

Note: WIPO's IPC-Technology concordance table is used to classify the data by fields of technology.

Source: WIPO Statistics Database 
As described in Section II, the economic literature has argued that firms in certain industries have engaged in patent portfolio races in response to an increased threat of holdup. This threat is especially pronounced for so-called complex technologies, defined as technologies in which the resulting products or processes consist of numerous separately patentable elements. By contrast, discrete technologies describe products or processes that consist of a single or relatively few patentable elements. ${ }^{21}$

We adopt the definition complex and discrete technologies developed by von Graevenitz et al. (2008) to explore whether filing growth differed for these two broad categories of technology. Between 1995 and 2008, complex technologies accounted for 74 percent of first filings and 63 percent of subsequent filings, whereas discrete technologies accounted for the remaining 26 and 37 percent, respectively. Figure 10 depicts the filing trends for these two broad technology categories, whereby filing figures are converted into index numbers with a common base year. Looking at first filings, filing growth for complex technologies has been consistently faster than for discrete technologies, especially since the mid-1990s.

Subsequent filings for the two technology types saw similar trends of zero/low growth up to the mid-1990s; however, from the mid-1990s onward, subsequent filings picked up for both types with substantially faster growth for complex technologies.

Figure 10: Filing trends for complex versus discrete technologies $(1972=100)$
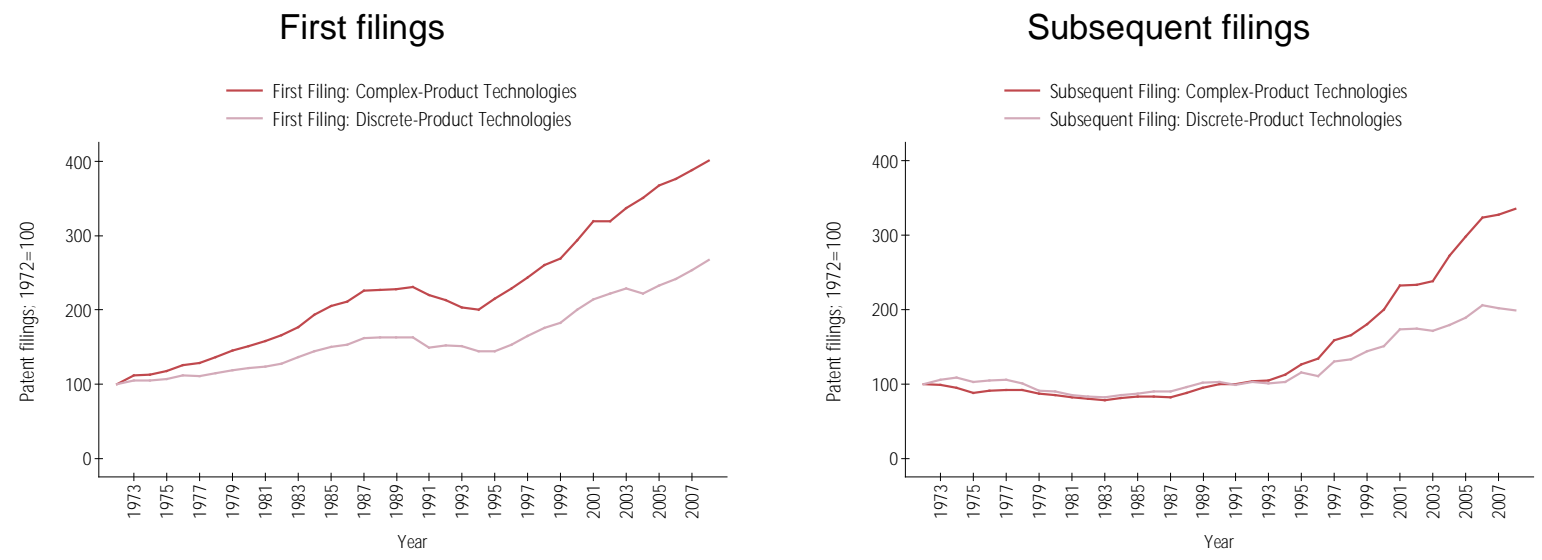

Note: WIPO's IPC-Technology concordance table is used to classify the data by fields of technology. The classification of complex and discrete technologies follows von Graevenitz et. al. (2008). See Annex A5 for details.

Source: WIPO Statistics Database

At first glance, these findings appear consistent with the prior literature on strategic patenting in complex technology industries. However, it is important to note that discrete technologies also saw fast growth in patenting, suggesting that the drivers of the patent surge go beyond strategic patenting behavior by firms exposed to holdup threats. In addition, it remains open to what degree the faster patenting growth in complex technologies was due to a "technological boom" - reflected in greater investments in innovation and increased productivity of innovation - or due to companies seeking out more patents for the same level of innovative activity. The marked increase in the patent yield for electrical machinery, computer technology and audiovisual technology (see figure 9) suggests that the latter influence was important for at least some complex technology industries. Yet, it was not sufficiently strong to push up the patent yield across all industries (see figure 7).

\footnotetext{
${ }^{21}$ See, for example, Cohen, et. al.(2000).
} 


\section{CONCLUSIONS}

The surge in patent filings over the past four decades raises important questions about its causes and its consequences for innovation. This study has sought to explore the factors behind the surge in filings worldwide. It documented how patent filings saw rapid growth during two periods. The first occurred between 1983 and 1990 and the second took place between 1995 and 2008, with the second period seeing faster average annual growth.

Of the top 15 patent offices, 10 offices saw considerable growth in patent filings. At the majority of these offices, the rise in filings started in the mid- to late 1990s. China and the Republic of Korea experienced double-digit growth.

Japanese applicants were the main source of filing growth during the first surge. They accounted for 18.9 percentage points of total growth (29 percent). For the second surge period, applicants from China contributed the most (19.4 percentage points) to overall growth (92.2 percent), followed by the US (18.5 percentage points), the Republic of Korea (14.3) and Japan (11.5).

We investigated three factors that may be behind the surge in worldwide filings:

- multiple filings for the same invention;

- changes in the patent yield; and

- patenting in specific fields of technology.

A breakdown of worldwide filings by first and subsequent filings reveals the following:

_ $\quad$ During the first surge, first filings accounted for 70.9 percent of worldwide filing growth and subsequent filings for the remainder. This suggests that the growth in worldwide filings was mainly due to new inventions.

- $\quad$ During the second surge, first (50\%) and subsequent (50\%) filings equally accounted for total growth in filings worldwide. In other words, both multiple filings and new inventions were drivers of the worldwide surge. Subsequent filings mostly represented filings abroad. The growth in the share of subsequent filings was most likely due to rapid growth in international commerce.

- The contribution of first and subsequent filings varied across offices and origins. New inventions were the main factors behind the growth in filings originating from China, Japan, the Republic of Korea, and the Russian Federation. Multiple filings were the main source of growth in filings originating from European countries, Canada and the US.

- $\quad$ There has been an increase in the use of the PCT system for subsequent filings. For the second surge period, PCT national phase entries accounted for most of the growth in subsequent filings.

The aggregate patent yield - first filings over real R\&D expenditure - has been on a continuous downward trend. In other words, changes in the worldwide patent yield cannot account for the patent surge worldwide. Most countries analyzed in this paper also show a downward trend in the patent yield. The US is the main exception, seeing an increasing patent yield between 1986 and 2005. 
Decomposing filing growth by field of technology suggests that no single field can account for the worldwide surge. Three of the broadly defined information and communication technologies (ICTS) - in particular, computer technology, digital communication, and telecommunications - were important sources of filing growth, but even their combined contribution accounted for less than a fifth of the overall growth.

Consistent with the prior literature, complex technologies saw faster filing growth than discrete technologies. This finding - and evidence of an increase in the patent yield for selected complex technology industries - point to strategic patenting in response to holdup threats as one driver of the surge. However, its ultimate empirical importance remains unclear. Indeed, reconciling the findings of studies focusing on patenting behavior in particular industries with economy-wide patent filing trends for different countries is an important area for future research. 


\section{References}

Blind, K., K. Cremers and E. Mueller. (2009). "The Influence of Strategic Patenting on Companies' Patent Portfolios." Research Policy, 38(2), 428-436.

Cohen, W. M., R.R. Nelson., and J.P. Walsh. (2000). "Protecting Their Intellectual Assets: Appropriability Conditions and Why U.S. Manufacturing Firms Patent (or Not)." National Bureau of Economic Research Working Paper, No. 7552.

Hall, B.H. (2005). "Exploring the Patent Explosion." The Journal of Technology Transfer, 30(2), 35-48.

Hall, B. H., and R.H. Ziedonis. (2001). "The Patent Paradox Revisited: An Empirical Study of Patenting in the U.S. Semiconductor Industry, 1979-1995." The RAND Journal of Economics, 32(1), 101-128.

Harhoff, D., B.H. Hall, G. von Graevenitz, K. Hoisl, and S. Wagner. (2007). "The Strategic Use of Patents and its Implications for Enterprise and Competition Policies." Report commissioned by European Commission.

Hu, A.G. and G.H. Jefferson. (2009). A Great Wall of Patents: What is Behind China's Recent Patent Explosion." Journal of Development Economics, 90, 57-68.

Jaffe, A. (2000), "The US patent system in transition: policy innovation and the innovation process", Research Policy, Vol. 29, pp. 531-557.

Kim, J. and G. Marschke (2004), "Accounting for the recent surge in U.S. patenting: "changes in R\&D expenditures, patent yields, and the high tech sector", Economics of Innovation and New Technology, Vol. 13(6), pp. 543-558.

Kortum, S. and J. Lerner (1999), "What is behind the recent surge in patenting?", Research Policy, Vol. 28(1), pp. 1-22.

Noel, M. and M. Schankerman. (2006). "Strategic Patenting and Software Innovation." Centre for Economic Performance Discussion Paper, 740. (London: London School of Economics and Political Science).

Rafiquzzaman, M. and L. Whewell (1998), "Recent jumps in patenting activities: comparative innovative performance of major industrial countries, patterns and explanations", Industry Canada Research Publications Program, Working Paper No. 27.

Shapiro, C. (2001), "Navigating the patent thicket: cross-licenses, patent pools, and standard-setting", in Jaffe, A., Lerner, J. and Stern, S. (edited), Innovation policy and the Economy, Vol. 1. MIT Press.

von Graevenitz, G., S. Wagner, and D. Harhoff (2008), "Incidence and Growth of Patent Thickets - the Impact of Technological Opportunities and Complexity", CEPR Discussion Paper No. DP6900.

Zhang, H. (2010), "What is behind the recent surge in patenting in China?", International Journal of Business and Management, Vol. 5(10), pp. 83-91.

Ziedonis, R. (2004), “Don't fence me in: fragmented markets for technology and the patent acquisition strategies of firms", Management Science, Vol. 50(6), pp. 804-820.

WIPO (2012). "World Intellectual Property Indicators 2012." (Geneva, WIPO). 


\section{ANNEX A1: COMPARISON OF WIPO PATENT FAMILY WITH WIPO SURVEY DATABASES}

This study mainly relies on WIPO's patent family database - a combination of the EPO's PATSTAT database and the WIPO Statistics Database. The WIPO Statistics Database includes records of all PCT applications, records of PCT national phase entries (NPE) at certain offices, as well as aggregate patent statistics collected by WIPO through its annual IP Statistics Survey ("survey data"). The PATSTAT database contains individual records of published national applications covering more than 130 offices.

For the present study, using the WIPO patent family database has certain advantages. It allows for the breakdown of data by office, origin, first and subsequent filings, and by field of technology. To build the family database, we firstly "cleaned" the PATSTAT database. This process involved removing PCT designation data and duplicate publication records. We grouped the "clean" PATSTAT records according to their relationship: first, subsequent, and continuations or divisional filings. We then supplemented the PCT NPE data in the PATSTAT database with available PCT NPE data from the WIPO Statistics Database. ${ }^{22}$ Lastly, we compared the family database with survey data to evaluate the accuracy of the family database.

Figure A1 compares total application data from WIPO's Statistics Survey and WIPO's patent family data. We expect the patent family data to show fewer patents than the WIPO Statistics Database because the former includes only published applications, whereas the latter captures all applications. Both data series follow the same trend except for the latest available year of 2008. For the 1972-2008 period, the patent family data include 87 percent of the worldwide data collected through the IP Statistics Survey.

The world average may hide more pronounced data discrepancies at the office level. Therefore, we analyze the two data series for the top 15 offices. ${ }^{23}$ Table A1 provides summary statistics. It shows that the family data include more than 80 percent of total filings for all offices, except for Mexico and the Russian Federation. Figure A2 graphically presents the two series. It shows that they follow a similar trend for all offices except Australia, Israel, and South Africa. ${ }^{24}$

From these comparisons, we conclude that the patent family data reasonably captures time series trends at the worldwide level and for most offices. The present study therefore relies on this data source, enabling richer analyses. However, the study only analyzes data up to 2008 to avoid distortions due to missing data.

\footnotetext{
${ }^{22}$ PCT NPE data were added from the WIPO Statistics Database due to the fact that these data were incomplete in or missing from the PATSTAT database.

${ }^{23}$ We selected the top 15 offices according to the total number of filings over the $2000-2008$ period. Brazil and India are two of the top 15 offices, but were excluded from the sample because of inconsistencies in their data. The top 15 offices accounted for around 93 percent of all patent families.

${ }^{24}$ For these three counties, the series tend to diverge in later years. However, they only account for a small proportion of total patent families. We therefore do not expect them to affect the conclusions of this study.
} 
Figure A1: Total patent filings based on patent family and survey data

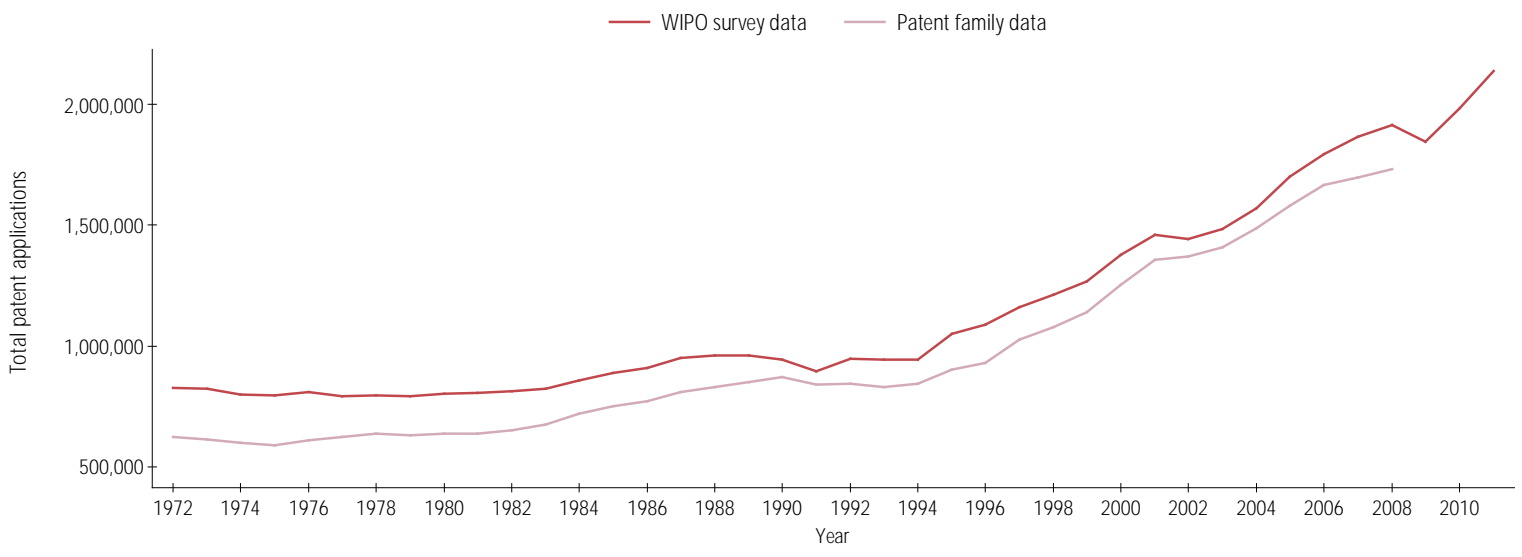

Source: WIPO Statistics Database

Table A1: Average number of filings per year for the top 15 offices

\begin{tabular}{lrrr}
\hline Patent Office & Patent family & Survey data Family I Survey | \\
\hline Australia & 15,026 & 17,721 & 84.8 \\
\hline Canada & 27,948 & 30,446 & 91.8 \\
\hline China & 70,432 & 67,982 & 103.6 \\
\hline European Patent Office & 70,380 & 69,292 & 101.6 \\
\hline France & 21,728 & 23,070 & 94.2 \\
\hline Germany & 43,302 & 52,937 & 81.8 \\
\hline Israel & 4,550 & 4,260 & 106.8 \\
\hline Italy & 13,265 & 12,855 & 103.2 \\
\hline Japan & 311,729 & 311,846 & 100.0 \\
\hline Mexico & 5,398 & 7,645 & 70.6 \\
\hline Republic of Korea & 46,382 & 53,198 & 87.2 \\
\hline Russian Federation & 23,774 & 30,726 & 77.4 \\
\hline South Africa & 7,148 & 7,540 & 94.8 \\
\hline United Kingdom & 31,183 & 35,502 & 87.8 \\
\hline United States & 163,921 & 202,156 & 81.1 \\
\hline varis
\end{tabular}

Note: The sample varies for offices and depends on data availability for both data sources.

Source: WIPO Statistics Database 
Figure A2: Trends in patent filings based on patent family and survey data: top 15 offices plus India

Office: Australia

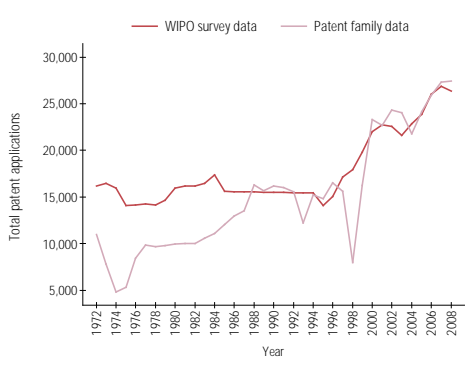

Office: European Patent Office

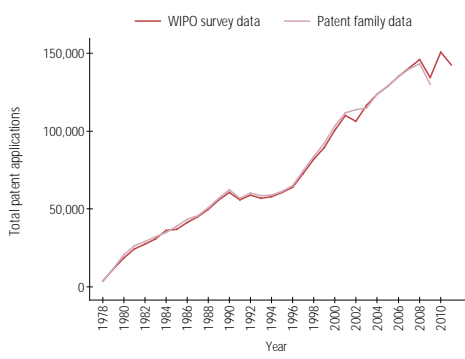

Office: Israel

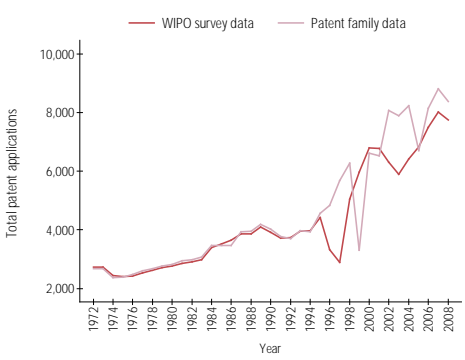

Office: Mexico

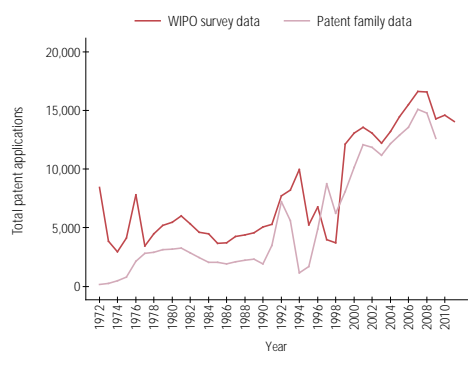

Office: South Africa

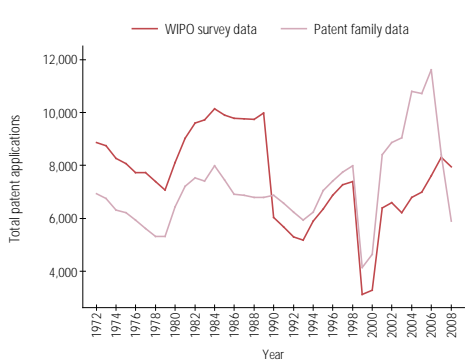

Source: WIPO Statistics Database
Office: Canada

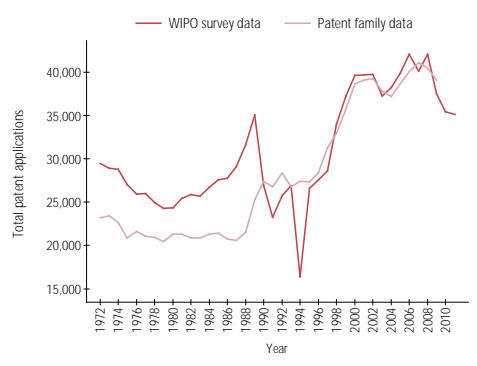

Office: France

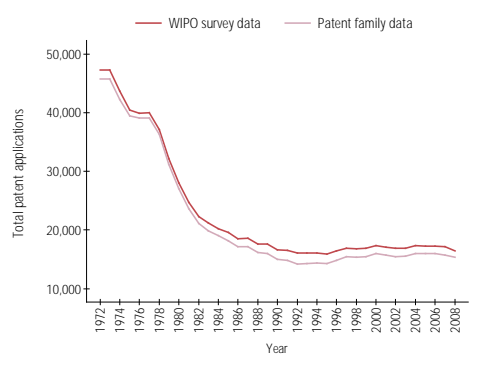

Office: Italy

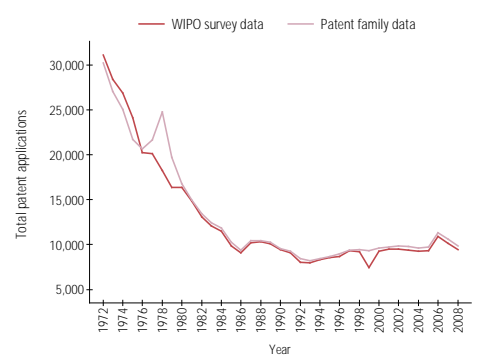

Office: Republic of Korea

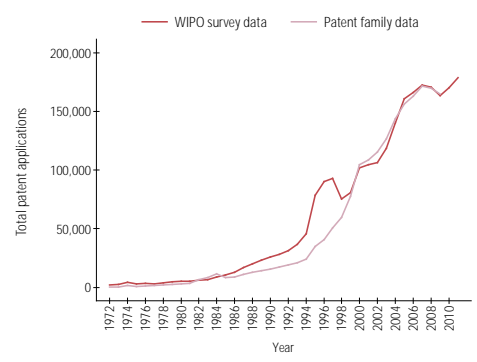

Office: United Kingdom

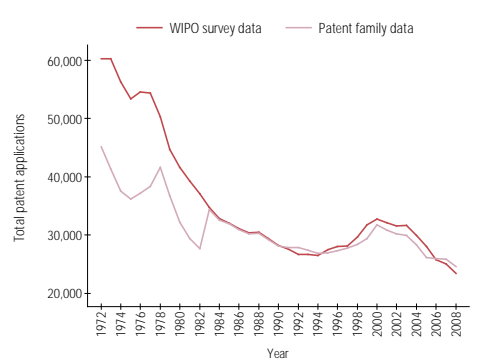

Office: China

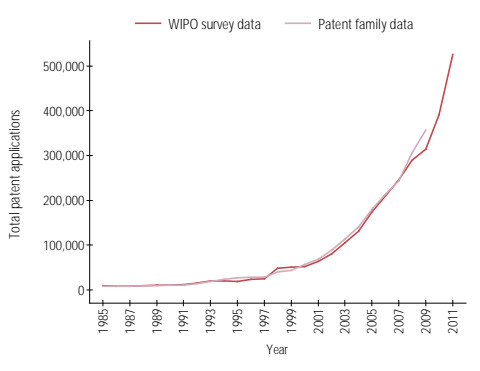

Office: Germany

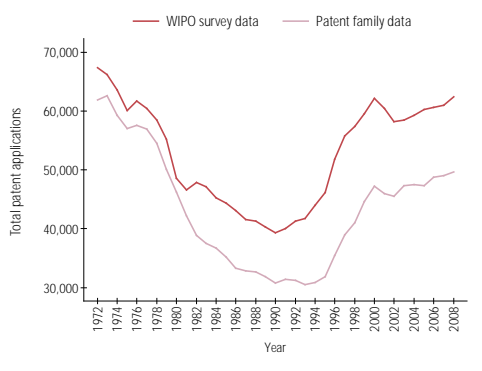

Office: Japan

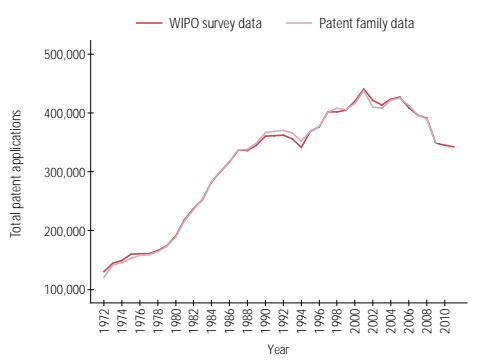

Office: Russian Federation

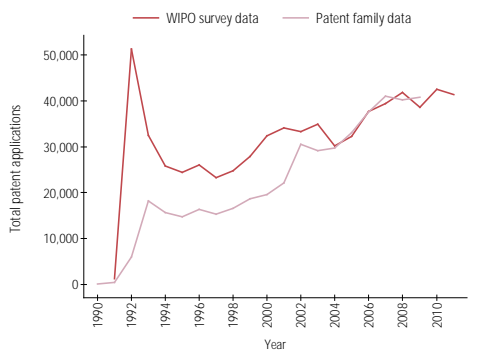

Office: United States of America

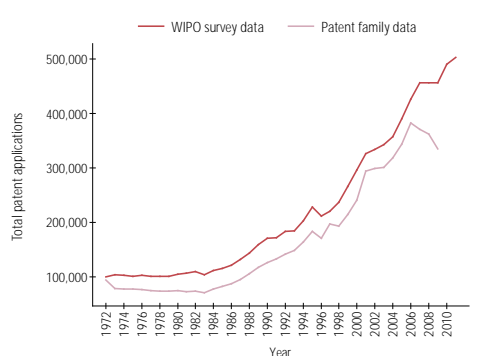




\section{ANNEX A2: PATENT FILINGS BY APPLICATION TYPES - TOP 15 OFFICES}

Office: Australia
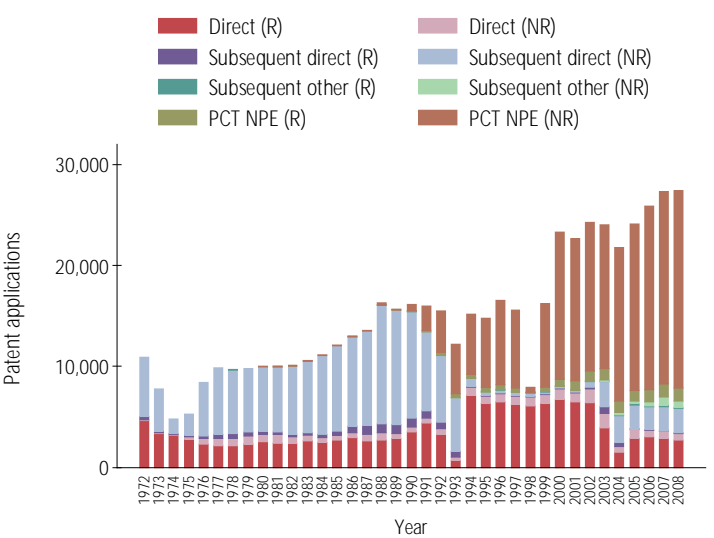

Office: China

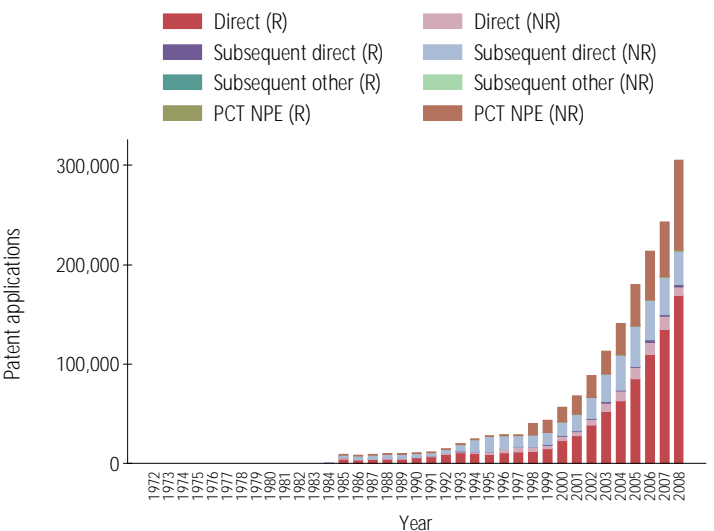

Office: France

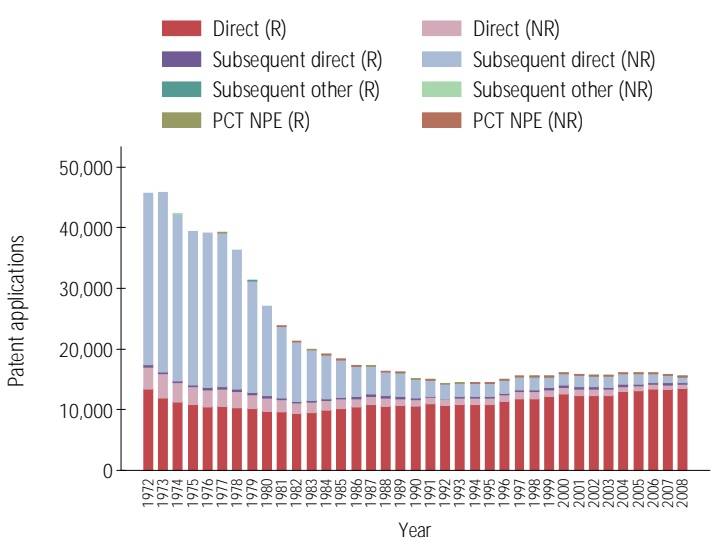

Office: Canada

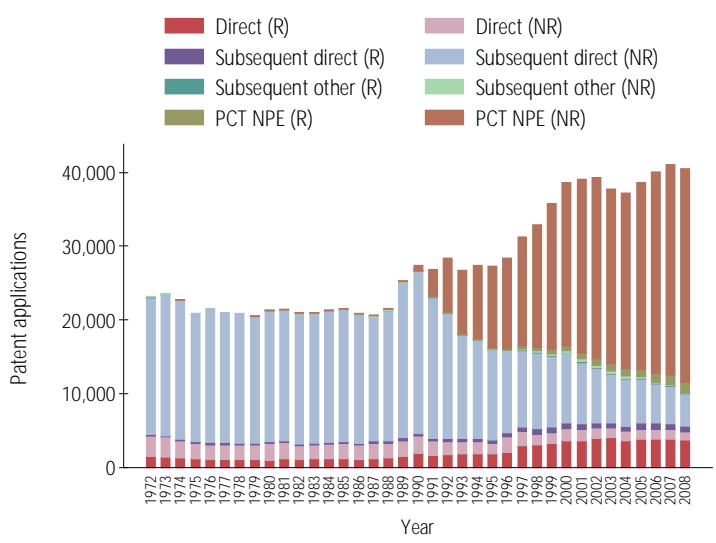

Office: European Patent Office

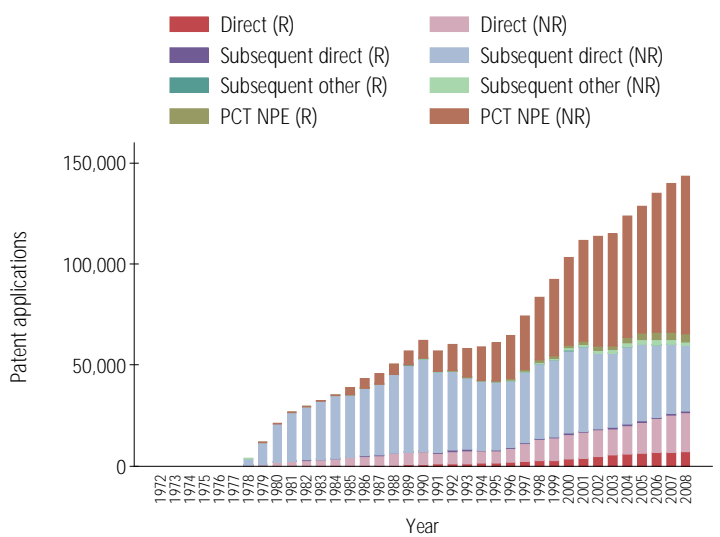

Office: Germany

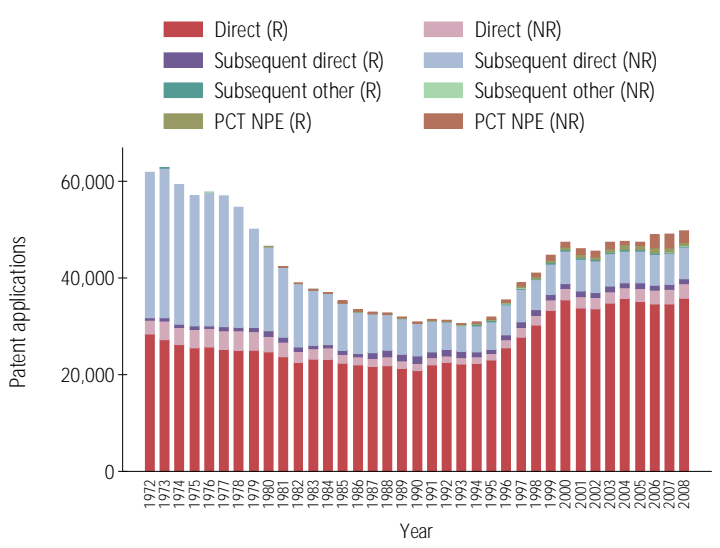


Office: Israel
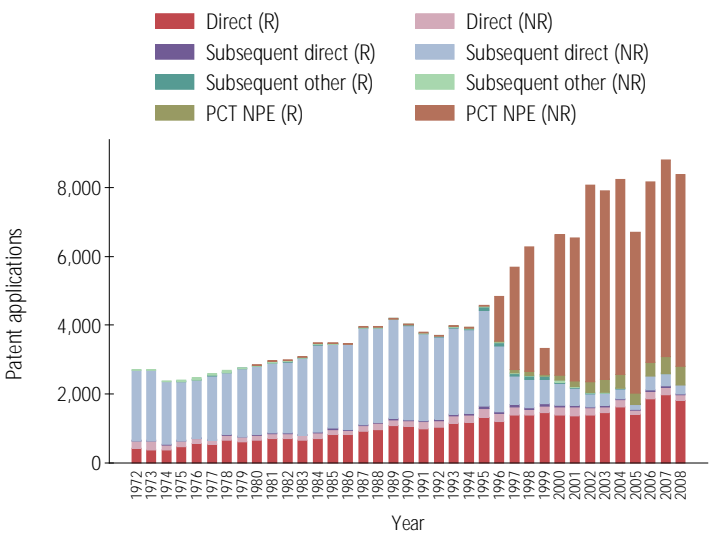

Office: Japan

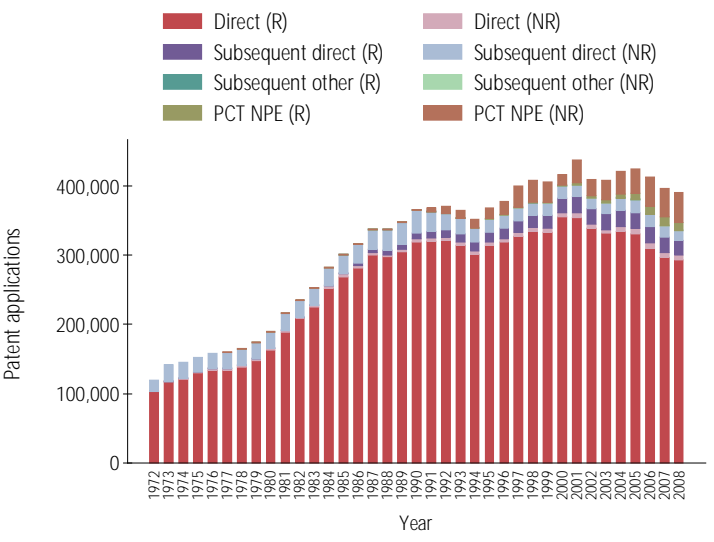

Office: Republic of Korea

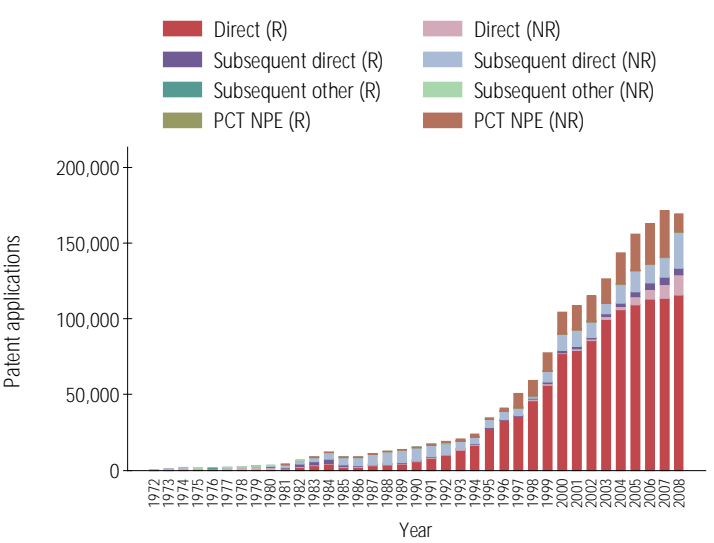

Office: Italy

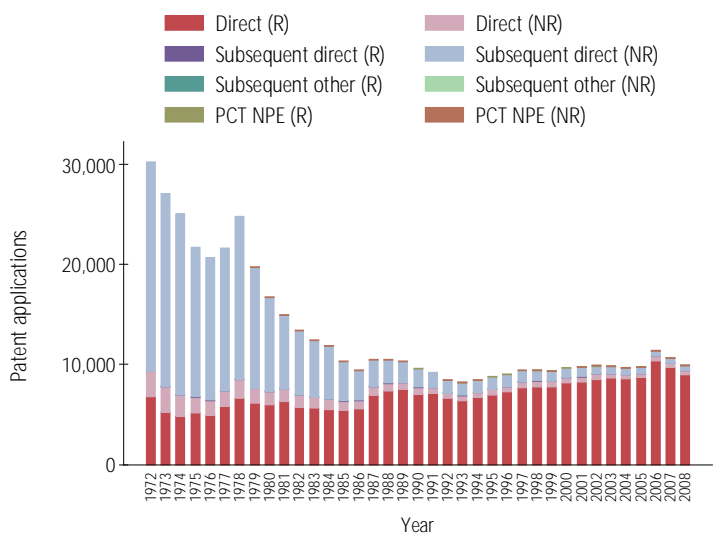

Office: Mexico

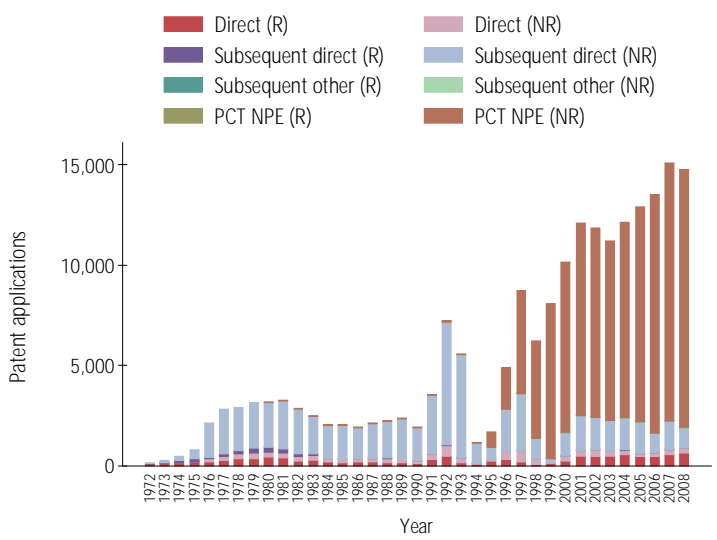

Office: Russian Federation

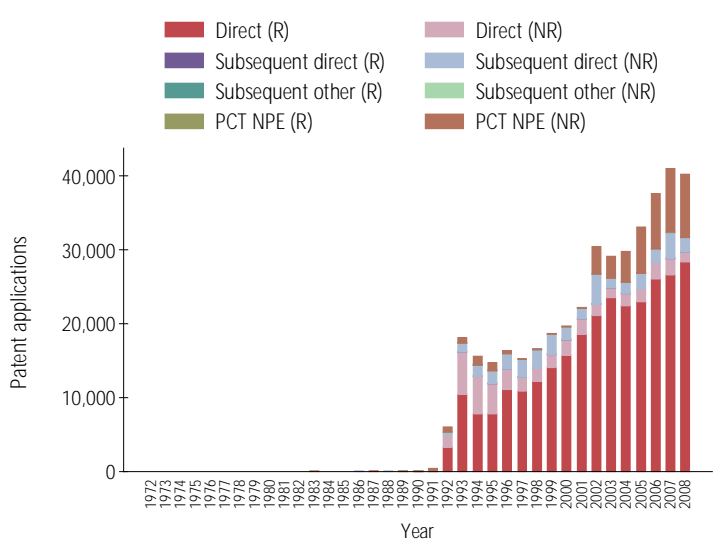


Office: South Africa

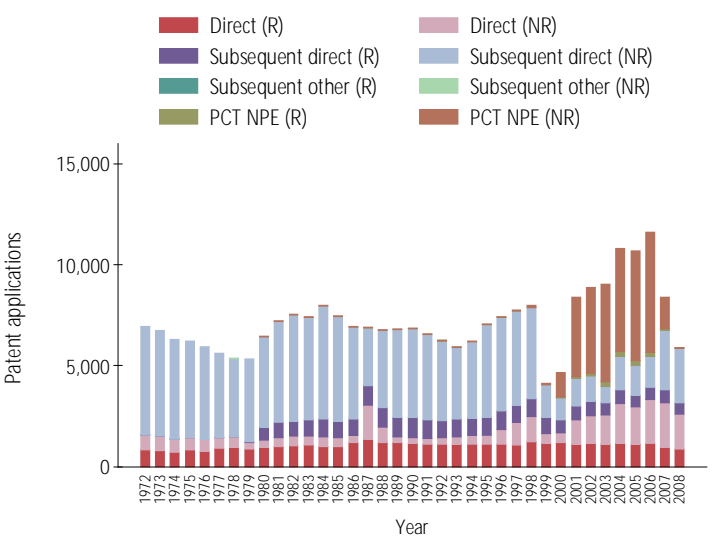

Office: United States of America

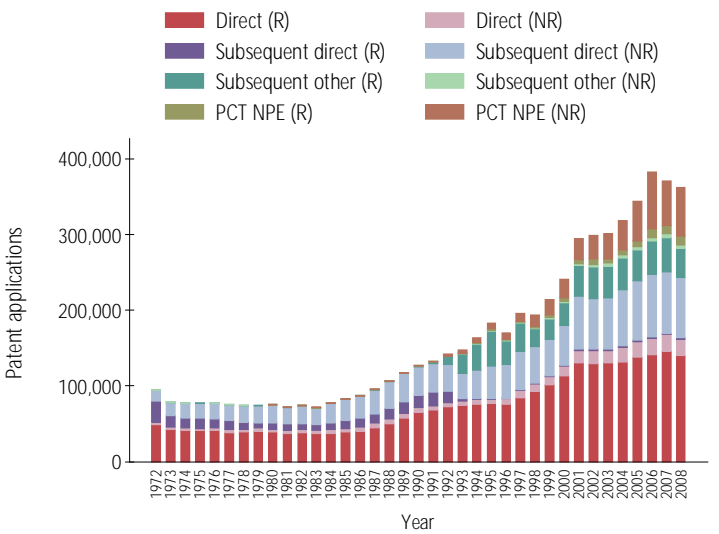

Office: United Kingdom

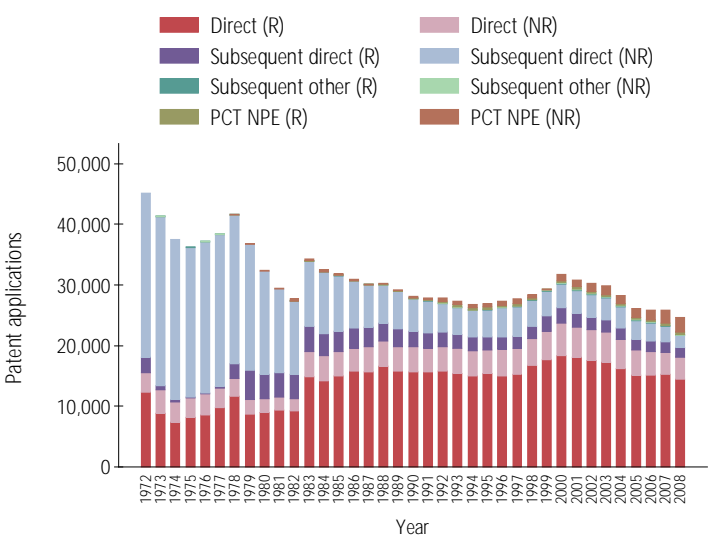

Note: Member States of the European Patent Convention have seen a drop in filings. This is likely due to the creation of the EPO. Many applicants likely chose to file at the EPO rather than at a national office if they also seek protection in other EPO member states.

Source: WIPO Statistics Database 


\section{ANNEX A3: PATENT FILINGS BY APPLICATION TYPES - TOP 15 ORIGINS}

Origin: Australia

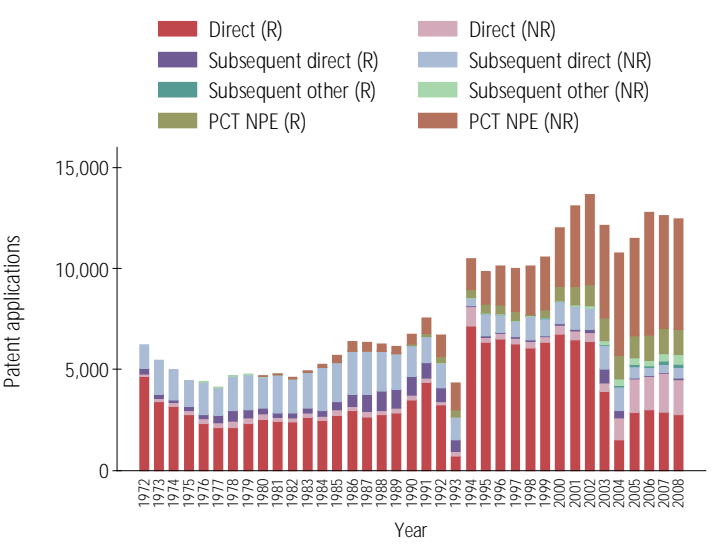

Origin: China

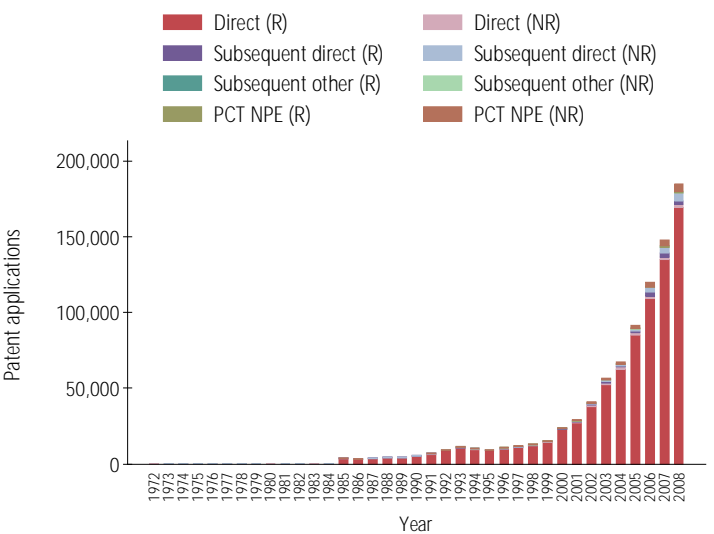

Origin: France

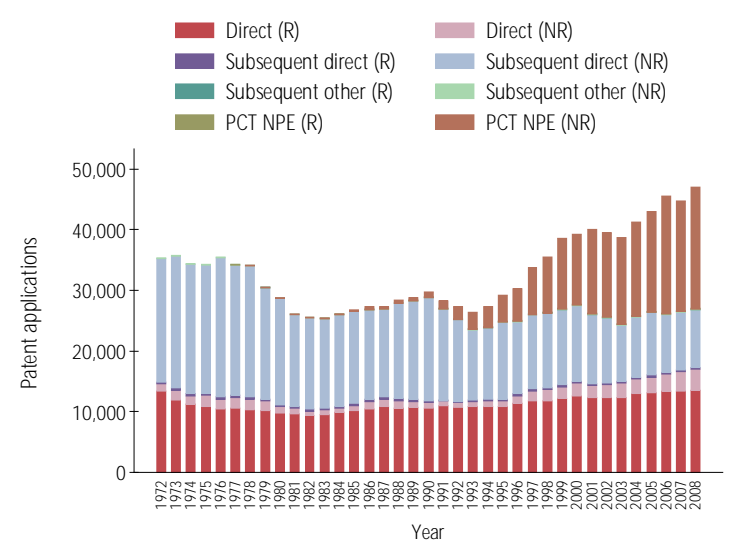

Origin: Canada

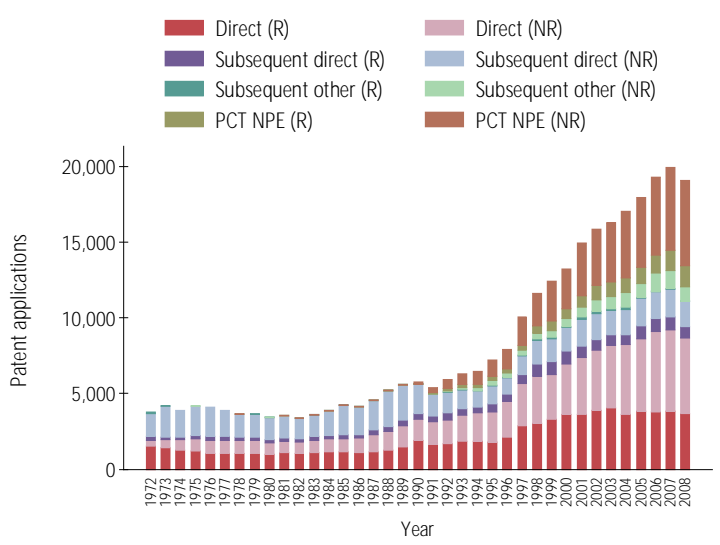

Origin: Finland

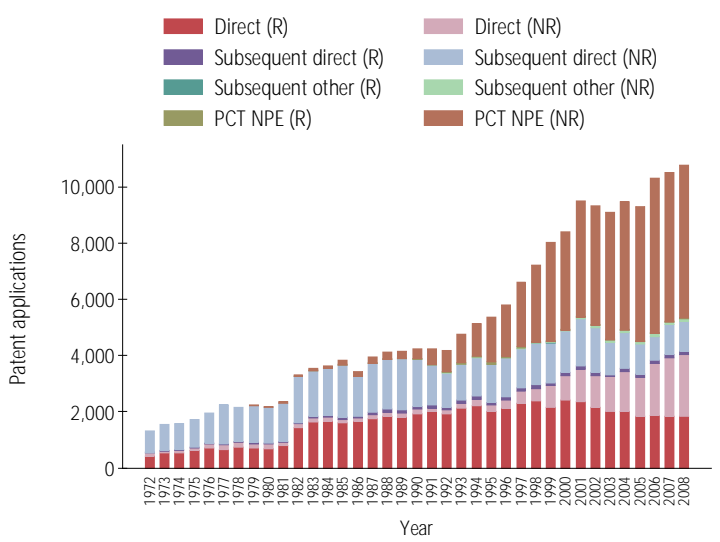

Origin: Germany

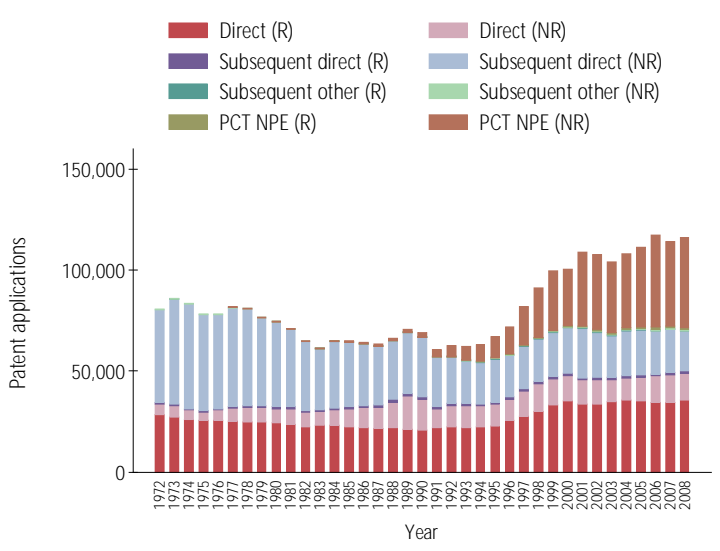


Origin: Italy

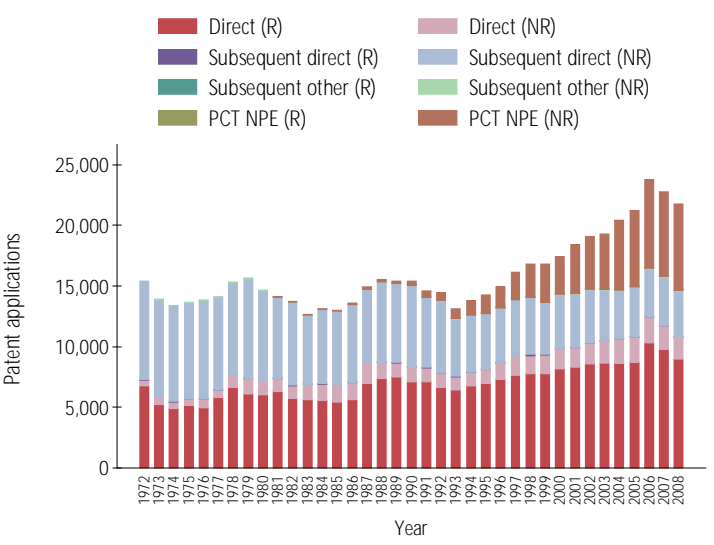

Origin: Netherlands

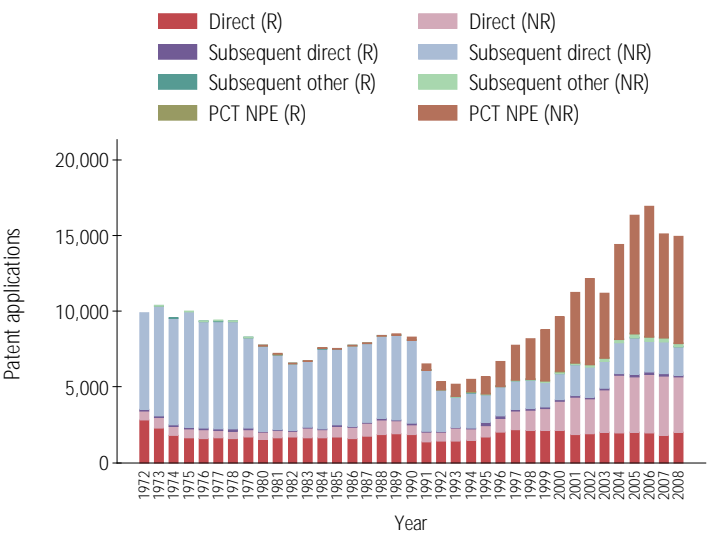

Origin: Russian Federation

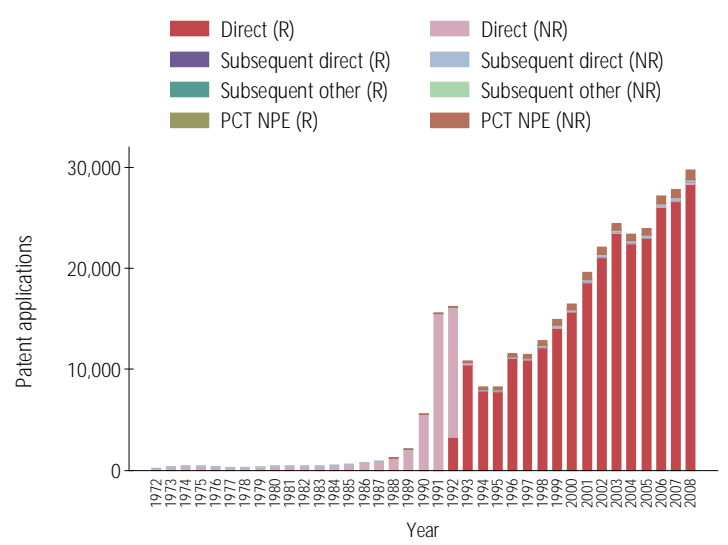

Origin: Japan

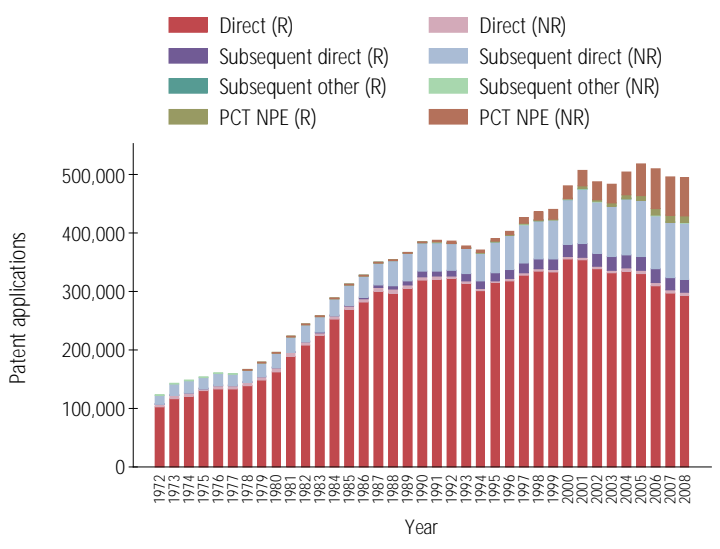

Origin: Republic of Korea
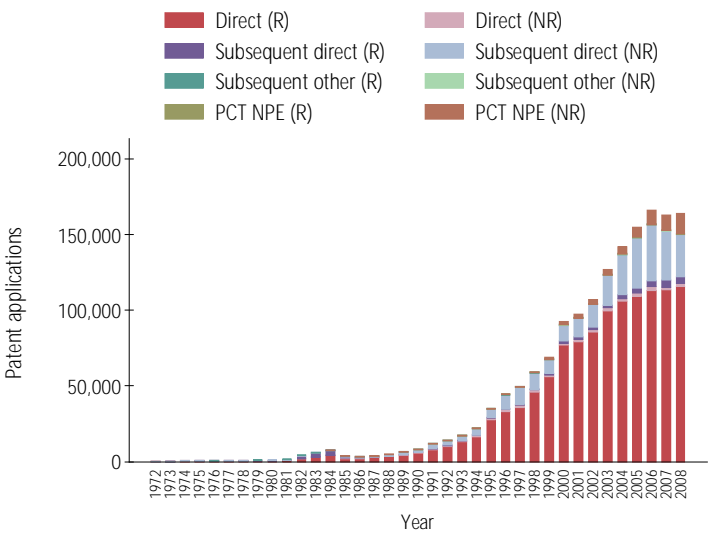

Origin: Sweden

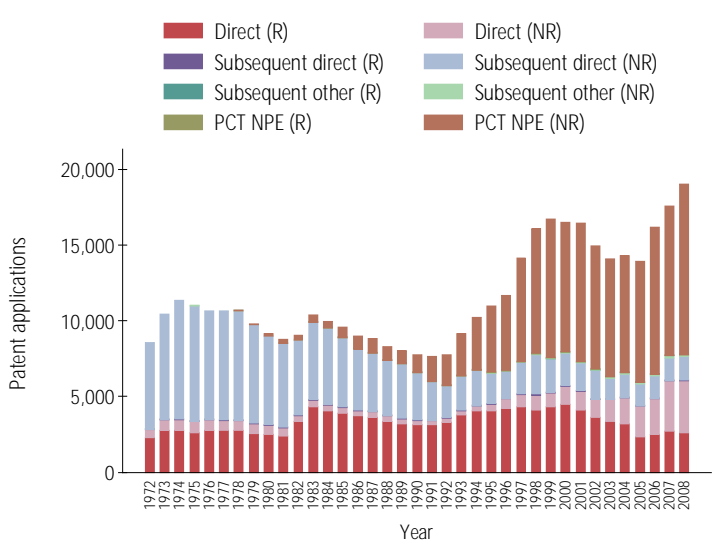



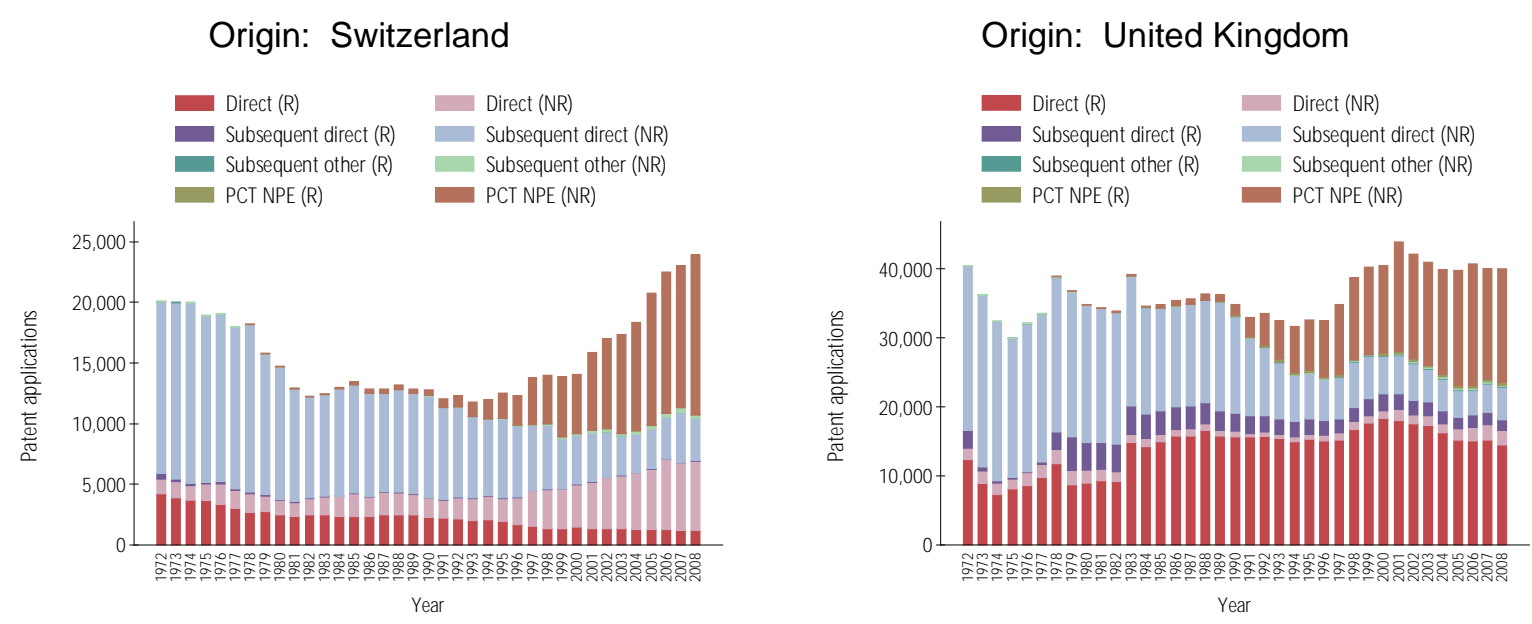

Origin: United States of America

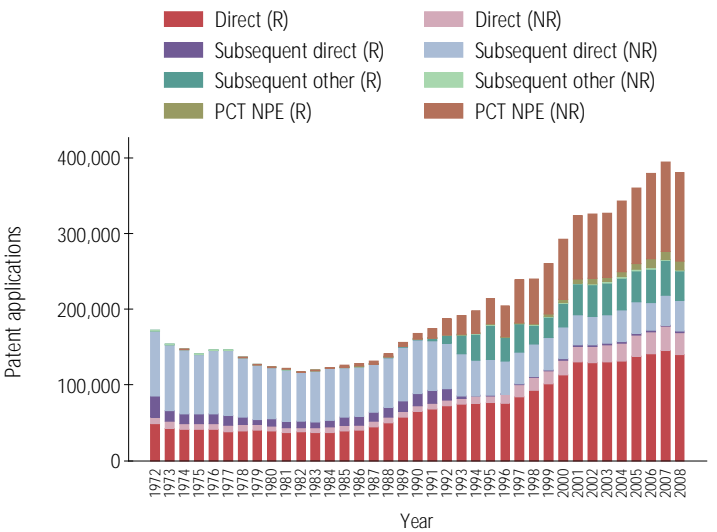

Source: WIPO Statistics Database 
ANNEX A4

\section{Classification of complex and discrete technologies}

\begin{tabular}{|c|c|}
\hline Technology Fields & Classification \\
\hline \multicolumn{2}{|l|}{ Electrical engineering } \\
\hline Electrical machinery, apparatus, energy & Complex \\
\hline Audio-visual technology & Complex \\
\hline Telecommunications & Complex \\
\hline Digital communication & Complex \\
\hline Basic communication processes & Complex \\
\hline Computer technology & Complex \\
\hline IT methods for management & Complex \\
\hline Semiconductors & Complex \\
\hline \multicolumn{2}{|l|}{ Instruments } \\
\hline Optics & Complex \\
\hline Measurement & Complex \\
\hline Analysis of biological materials & Discrete \\
\hline Medical technology & Complex \\
\hline \multicolumn{2}{|l|}{ Chemistry } \\
\hline Organic fine chemistry & Discrete \\
\hline Biotechnology & Discrete \\
\hline Pharmaceuticals & Discrete \\
\hline Macromolecular chemistry, polymers & Discrete \\
\hline Food chemistry & Discrete \\
\hline Basic materials chemistry & Discrete \\
\hline Materials, metallurgy & Discrete \\
\hline Surface technology, coating & Discrete \\
\hline Micro-structural and nano-technology & Complex \\
\hline Chemical engineering & Discrete \\
\hline Environmental technology & Complex \\
\hline \multicolumn{2}{|l|}{ Mechanical engineering } \\
\hline Handling & Discrete \\
\hline Machine tools & Complex \\
\hline Engines, pumps, turbines & Complex \\
\hline Textile and paper machines & Discrete \\
\hline Thermal processes and apparatus & Complex \\
\hline Mechanical elements & Complex \\
\hline Transport & Complex \\
\hline \multicolumn{2}{|l|}{ Other fields } \\
\hline Civil engineering & Complex \\
\hline
\end{tabular}

Note: This classification follows van Graevenitz et. al. (2008). 